\title{
Research Paper \\ Investigating the conceptual model of career guidance and entrepreneurship components incorporated in the content of the first secondary school textbooks
}

\author{
Ali Akbar Dahaghin ${ }^{1}$, Kiumars Farahbakhsh ${ }^{2}$, Atusa Klantar Hormozi ${ }^{2}$, Ali Reza Sadeghi ${ }^{3}$ \\ 1. Ph.D Student in Counseling, Allameh Tabataba'i University, Tehran, Iran. \\ 2. Associate Professor, Counseling Department, Allameh Tabataba'i University, Tehran, Iran. \\ 3. Associate Professor, Curriculum Planning Department, Allameh Tabataba'i University, Tehran, Iran.
}

\begin{abstract}
Citation: Dahaghin A.A, Farahbakhsh K, Klantar Hormozi A, Sadeghi A.R. Investigating the conceptual model of career guidance and entrepreneurship components incorporated in the content of the first secondary school textbooks. J of Psychological Science. 2022; 20(108): 2161-2180.
\end{abstract}

URL: https://psychologicalscience.ir/article-1-1303-fa.html
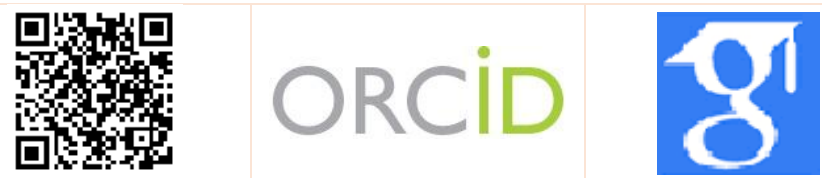

$10.52547 /$ JPS.20.108.2161

\section{A R T I C L E I N F O A B S T R A C T}

Keywords:

Career Guidance,

Entrepreneurial

Competence,

Content Analysis,

first secondary school

Received: 02 Jun 2021

Accepted: 19 Jul 2021

Available: 20 Feb 2022
Background: currently, due to the lack of career guidance program and entrepreneurship education in Iran first secondary school, the necessary preparations for the career path of students are done by incorporating these components in textbooks. Therefore, it is necessary to investigate the integrated model, which was neglected in previous studies

Aims: The aim of this study was to investigate the conceptual model of career guidance and entrepreneurship component integrated in the textbooks content of first secondary school.

Methods: This research used qualitative content analysis method to identify and extract components, and content analysis technique to organize the conceptual model. The statistical population was purposefully selected seventh to ninth grade textbooks for the 1400-99 academic year and samples including technology textbooks, three-level social studies, and seventh and eighth grade lifestyle Results: 125 codes and 20 basic themes were extracted; Essential codes and themes were identified and validated by 13 counseling and entrepreneurship experts by CVR method. 89 codes and 19 essential basic themes identified in the following to 3 organizing themes (career choice readiness, entrepreneurial competencies and basic competencies) and the comprehensive theme of career readiness, conceptual model was organized. $46.07 \%, 34.83 \%$ and $56.18 \%$ of the codes in the seventh to ninth have been neglected. The themes of career choice readiness include: career information $12.99 \%$, career and decision-making skills $6.96 \%$, career attitude $2.09 \%$ and the entrepreneurial competencies of $19.03 \%$ in the content of the textbooks have been considered.

Conclusion: The results showed that a significant percentage of the essential themes are neglected and the components are embedded locally in the content of textbooks. The comparison of integration model with development models of career choice indicates the dominance of the immediate view over the developmental of career choice, Therefore, the integration model doesn't have the necessary efficiency in career readiness of students.

* Corresponding Author: Kiumars Farahbakhsh, Associate Professor, Counseling Department, Allameh Tabataba'i University, Tehran, Iran.

E-mail: kiiumars@yahoo.com

Tel: (+98) 9131154635

2476-5740/ () 2021 The Authors. This is an open access article under the CC BY-NC-ND license

(https://creativecommons.org/licenses/by-nc/4.0/). 


\section{Extended Abstract}

\section{Introduction}

Career guidance is an inclusive term that has been used to describe a range of interventions including career education and counselling, that help people to move from a general understanding of life and work to a specific understanding of the realistic life, learning and work options that are open to them (ABCD, 2008). A variety of approaches, such as career develoment models, career guidance and education programs can provide knowledge, skills, and attitudes needed to career readiness. Gysbers (2013) believes that the behaviors and skills needed to achieve career readiness include: social competencies, diverse skills, positive work habits, personal qualities, personality and emotional states, and entrepreneurship.

EntreComp defines competence as "a set of knowledge, skills and attitudes" and "entrepreneurship" as "when you act upon opportunities and ideas and transform them into value for others" (Bacigalupo et al., 2016). In educational settings, entrepreneurship education on entrepreneurial competencies is focused on giving all students the opportunity to develop entrepreneurial ability (Palmer and Johansson, 2018). ICEE Progression Model (2018) considers students on a gradual journey of entrepreneurial learning that spends steps such as discovery, exploration and experimentation. According to Super career development theory (1990), secondary school students are in the process of growth and exploration. Hence, researches and experts have identified a good time for self-awareness, career exploration (Godbey and Gordon, 2019). Therefore, career guidance and entrepreneurship education programs in secondary school can significantly prepare students for successful entry into the changing, competitive and complex world of work.

Through the embedding approach, career guidance methods (Gysbers, 2008 and Collins and Barnes, 2017) and entrepreneurship education can be included in the curriculum. Infusion career guidance and personal development into all school subjects will lead to better results in meeting the challenges ahead in the world of work (Hiebert, 2010).

A review of ITHACA Group (2019) International Experiences of incorporating career education indicates that the world's education systems have recently shown widespread interest in crosscurricular approaches to incorporating guidance and career education. At the primary and secondary school level, many European countries are pursuing entrepreneurship education through cross-curricular methods and incorporating entrepreneurship education with other subjects as the dominant approach in the formal curriculum of these countries (European Commission, 2012).

In the first secondary school, the Iranian educational system has been considered as the only method of guidance and entrepreneurship education for acquiring entrepreneurial competencies and career maturity through integration in textbooks. A review of the research background in Iran showed that in this area, no research has been conducted with emphasis on theories of career development and entrepreneurial competencies in elementary and secondary school.

Therefore, it is necessary to investigate the incorporated conceptual model in order to evaluate the efficiency and measure the degree of compliance with the comprehensive school development guidance programs and career development models, which were neglected in previous studies.

Thus, the present study raises this year what components of career guidance and entrepreneurship are incorporated into the content of secondary school textbooks? What can be the essential themes and components to integrate into the textbooks in question? What are the essential themes neglected? What is the conceptual model based on those components? And to what extent are the characteristics of the model consistent with theories of career choise?

\section{Method}

This research used qualitative content analysis method to identify and extract components, and content analysis technique to organize the conceptual model. The statistical population was purposefully selected seventh to ninth grade textbooks for the 1400-99 academic year and samples including 


\section{Monthly Journal of Psychological Science}

Vol. 20, No. 108, Winter(March) 2022

technology textbooks, three-level social studies, and seventh and eighth grade lifestyle. In the data collection and face validity section, 3 entrepreneurship experts and 2 counselling experts were used, and in the CVR validation section, a total of 13 experts in the field of consulting and entrepreneurship were used. Specialists had at least a doctorate and experience in teaching and research in the fields of counselling, curriculum planning and entrepreneurship.

Content analysis worksheets were used to collect textbook content and CVR content validity questionnaire was used for validation. In order to familiarize with the themes of career guidance and entrepreneurship, first related theme in the research literature were studied and extracted; Then, the codes and themes related to these components were identified by qualitative content analysis of textbooks and recorded in the content analysis worksheets. To prepare a more complete list, the proposed list was completed by providing a list of codes and themes extracted from the textbooks to 5 counselling and entrepreneurship experts, after several round-trip steps without removing the code or theme.
Finally, by refining the codes and themes, then combining them, a set of codes and themes (125 codes and 20 basic themes) were obtained, which were validated by CVR method. According to the Lawshe's Table, the minimum validity required for 13 people is at least 0.54 . Therefore, components with a minimum of 0.54 agreement were selected. Out of 20 themes and 125 codes, 19 themes and 89 codes were deemed necessary from the point of view of experts. 89 codes and 19 essential basic themes identified in the following to 3 organizing themes (career choice readiness, entrepreneurial competencies and basic competencies) was organized. These three themes were provided in the form of career readiness competencies as a comprehensive theme to provide a conceptual model through Thematic analysis.

\section{Results}

The conceptual model of career guidance and entrepreneurship components of secondary school textbooks is given in Table 1 in the form of a comprehensive theme, three organizing themes, and 19 basic themes, with a frequency of seventh to ninth grade.

Table 1. Conceptual model of career guidance and entrepreneurship components of secondary school textbooks comprehensive theme of career readiness competencies

\begin{tabular}{|c|c|c|c|c|c|c|}
\hline \multirow{2}{*}{$\begin{array}{l}\text { Organizing } \\
\text { themes }\end{array}$} & \multirow{2}{*}{ Basic themes } & \multicolumn{3}{|c|}{ frequency } & \multirow{2}{*}{$\begin{array}{c}\text { Total } \\
\text { frequency }\end{array}$} & \multirow{2}{*}{$\begin{array}{l}\text { Percentages } \\
\text { of frequency }\end{array}$} \\
\hline & & $9^{\text {th }}$ grade & $8^{\text {th }}$ grade & $7^{\text {th }}$ grade & & \\
\hline \multirow{4}{*}{$\begin{array}{l}\text { career choice } \\
\text { readiness } \\
\text { competencies }\end{array}$} & Career information & 45 & 24 & 43 & 112 & $12 / 99 \%$ \\
\hline & Career skills & 21 & 9 & 8 & 38 & $4 / 41 \%$ \\
\hline & decision making skills & 1 & 21 & 0 & 22 & $2 / 55 \%$ \\
\hline & Career attitude & 7 & 8 & 3 & 18 & $2 / 09 \%$ \\
\hline \multirow{4}{*}{$\begin{array}{l}\text { entrepreneurial } \\
\text { competencies }\end{array}$} & Financial and economic literacy & 7 & 7 & 27 & 41 & $4 / 76 \%$ \\
\hline & Creative thinking & 17 & 28 & 32 & 77 & $8 / 93 \%$ \\
\hline & Opportunity recognition & 1 & 1 & 3 & 5 & $0 / 58 \%$ \\
\hline & Entrepreneurial attitude & 8 & 17 & 16 & 41 & $4 / 76 \%$ \\
\hline \multirow{11}{*}{$\begin{array}{c}\text { basic } \\
\text { competencies }\end{array}$} & Information and Communication Technology Literacy & 14 & 16 & 25 & 55 & $6 / 38 \%$ \\
\hline & Critical thinking & 9 & 16 & 21 & 46 & $5 / 34 \%$ \\
\hline & Problem-solving & 7 & 9 & 13 & 29 & $3 / 36 \%$ \\
\hline & Planning skills & 15 & 11 & 7 & 33 & $3 / 83 \%$ \\
\hline & Communication skills & 0 & 0 & 0 & 0 & $0 / 00 \%$ \\
\hline & Teamwork skills & 7 & 22 & 38 & 67 & $777 \%$ \\
\hline & Leadership skills & 0 & 0 & 0 & 0 & $0 / 00 \%$ \\
\hline & Assertiveness skills & 19 & 23 & 40 & 82 & $9 / 51 \%$ \\
\hline & Emotional management & 0 & 27 & 12 & 29 & $4 / 52 \%$ \\
\hline & Self development & 3 & 28 & 32 & 63 & $7 / 31 \%$ \\
\hline & Professional ethics & 25 & 26 & 33 & 94 & $10 / 90 \%$ \\
\hline $\begin{array}{c}\text { Total } \\
\text { frequency }\end{array}$ & $* * * * * * *$ & 206 & 303 & 353 & 862 & $100 / 00 \%$ \\
\hline
\end{tabular}


In order to describe and explain more precisely the two themes, career choice readiness competencies and entrepreneurial competencies were presented separately in Tables (2 and 3).
According to Table 2, the most frequent theme was career information with $12.99 \%$ and career choice skills with $0.12 \%$ was the least.

According to Table 7, the most frequent theme was creative thinking with $8.93 \%$ and opportunity recognition skills with $0.58 \%$ was the least.

Table 2. career choice readiness competencies of secondary school textbooks

\begin{tabular}{|c|c|c|c|c|c|c|}
\hline \multirow{2}{*}{ Organizing themes } & \multirow{2}{*}{ Basic themes } & \multicolumn{3}{|c|}{ frequency } & \multirow{2}{*}{$\begin{array}{c}\text { Total } \\
\text { frequency }\end{array}$} & \multirow{2}{*}{$\begin{array}{c}\text { Percentages of } \\
\text { frequency }\end{array}$} \\
\hline & & $9^{\text {th }}$ grade & $8^{\text {th }}$ grade & $7^{\text {th }}$ grade & & \\
\hline \multirow{7}{*}{$\begin{array}{l}\text { career choice readiness } \\
\text { competencies }\end{array}$} & Career information & 45 & 24 & 43 & 112 & $12 / 99 \%$ \\
\hline & Career exploration skills & 8 & 5 & 2 & 15 & $1 / 74 \%$ \\
\hline & Career information acquisition skills & 3 & 3 & 4 & 10 & $1 / 16 \%$ \\
\hline & Career self-awareness & 9 & 1 & 2 & 12 & $1 / 39 \%$ \\
\hline & career choice skills & 1 & 0 & 0 & 1 & $0 / 12 \%$ \\
\hline & decision making skills & 1 & 21 & 0 & 22 & $2 / 55 \%$ \\
\hline & Career attitude & 7 & 8 & 3 & 18 & $2 / 09 \%$ \\
\hline Total frequency & $* * * * * * *$ & & & & & $22 / 04 \%$ \\
\hline
\end{tabular}

Table 3. entrepreneurial competencies of secondary school textbooks

\begin{tabular}{|c|c|c|c|c|c|c|}
\hline \multirow{2}{*}{ Organizing themes } & \multirow{2}{*}{ Basic themes } & \multicolumn{3}{|c|}{ frequency } & \multirow{2}{*}{$\begin{array}{c}\text { Total } \\
\text { frequency }\end{array}$} & \multirow{2}{*}{$\begin{array}{c}\text { Percentages of } \\
\text { frequency }\end{array}$} \\
\hline & & $9^{\text {th }}$ grade & $8^{\text {th }}$ grade & $7^{\text {th }}$ grade & & \\
\hline & Financial and economic literacy & 7 & 7 & 27 & 41 & $4 / 76 \%$ \\
\hline entrepreneurial & Creative thinking & 17 & 28 & 32 & 77 & $8 / 93 \%$ \\
\hline \multirow[t]{2}{*}{ competencies } & Opportunity recognition & 1 & 1 & 3 & 5 & $0 / 58 \%$ \\
\hline & Entrepreneurial attitude & 8 & 17 & 16 & 41 & $4 / 76 \%$ \\
\hline Total frequency & $* * * * * * *$ & 33 & 53 & 78 & 164 & $19 / 03 \%$ \\
\hline
\end{tabular}

\section{Conclusion}

In order to investigate the conceptual model of career guidance and entrepreneurship component integrated in the textbooks content of first secondary school, the themes approved by research experts were compared with theoretical perspectives and research literature. Also, the frequency of themes, codes and neglected themes and the trend of key themes (ascending / descending and continuity / discontinuity) in the content of textbooks were considered as indicators and explanations of the model.

The findings of the present study show that insufficient attention has been paid to the themes related to career choice readiness except for career information.

Despite the emphasis on career self-awareness according to experts in this research and most career choice theories such as trait-factor theories (selfknowledge in Parsons and Holland theory) and career development theories under headings such as selfconcept, super development theory and Gottfredson (Patton and McMahon, 2006), little attention to career self-awareness in the content of $7^{\text {th }}$ and $8^{\text {th }}$ grade textbooks is inconsistent with the views of experts in the present study and career theories. The neglect of career decision-making skills in the $7^{\text {th }}$ grade and little attention in the $9^{\text {th }}$ grade indicate that career components are not incorporated into textbooks based on theories of career development.

The results show that in theme of entrepreneurial competence, the most attention has been paid to creative thinking in the seventh and eighth grades and the least to opportunity recognition. Furthermore, the frequency of entrepreneurial competencies from the seventh to the ninth grade shows a downward trend, which is inconsistent with the entrepreneurial learning journey proposed in the ICEE Progression Model (2018). From 19 basic themes approved by experts, two basic themes of communication skills, leadership skills in the seventh to ninth grades; decision making skills in seventh grade, emotional management in ninth grade, all subcodes are neglected, also $46.07 \%$ of the codes in the seventh grade, $34.83 \%$ in the eighth grade and $56.18 \%$ in the ninth grade. 
Overall, the results of model explanation showed that a significant percentage of the essential themes are neglected, the components are embedded locally in the content of textbooks, also little attention paid to career choice skills in seventh and eighth grade, so the comparison of integration model with career theories and models indicates the dominance of the immediate view over the developmental of career choice. On the other hand, little attention to the content of opportunity recognition and the downward trend of other themes of entrepreneurial competencies indicates that the integration model doesn't have enough efficiency in career readiness of students.

Very little empirical research in career guidance and entrepreneurship education, especially in secodary school, limited researchers in comparing research findings, and researchers had to compare them with career theories and models.

According to the results of the research, in order to improve the pattern of incorporation the essential components of guidance and entrepreneurship in the textbooks of the first secondary school, in order to improvement career readiness and entrepreneurial competencies, the following suggestions are also presented:

The incorporation of career guidance and entrepreneurship components in textbooks should be aligned with theories of career development.
Neglected thems: communication and leadership skills - as basic competencies - at all grades and decision-making skills - as the core of career choice in the 7 th grade, emotional management - as an influential factor in decision making skills - in the 9th grade, should be embedded in secondary textbooks' content.

In designing the goals of career and entrepreneurship education program to the concepts of entrepreneurial self-efficacy and Career decision-making selfefficacy as two key elements and predictors of entrepreneurial intention and career choice readiness should be considered by curriculum planning and school career guidance experts in the first secondary schools.

\section{Ethical Considerations}

Compliance with ethical guidelines: The authors extracter this article from the $\mathrm{PhD}$ under No 548 date, 11.30.2020 in the Counseling Department, Allameh Tabataba'i University, Tehran.

Funding: This study was conducted as $\mathrm{PhD}$ thesis with no financial support.

Authors' contribution: The first author was the main author, the second was the supervisor and the third and forth were the advisors.

Conflict of interest: The authors declare no conflicting interests for this study.

Acknowledgments: I would like to appreciate the supervisor, the advisors and the expert participants. 
مقاله يزورهشى

وارسى التوى مفهومى مؤلفه هاى راهنمايى شغلى و كار آفرينى تلفيق شده در محتواى كتب درسى دوره متوسطه

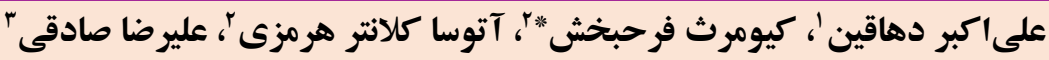

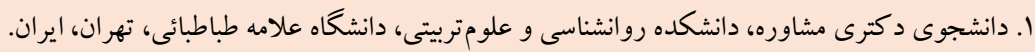

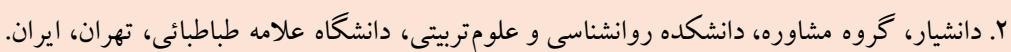

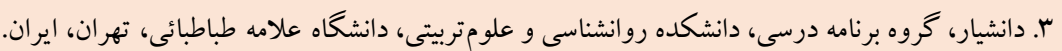

زمينه: درحال حاضر با توجه به فقدان برنامه راهنمايى شغلى و آموزش كار آفرينى در دوره متوسطه اول ايران، آماد كىهاى لازم براى مسير

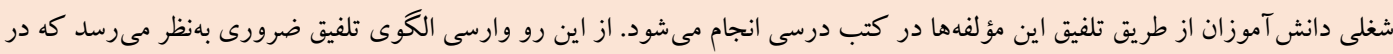
مطالعات بيشين مغفول مانده است. هدف: هدف يُزوهش حاضر وارسى الكوى مفهومى مؤلفههاى راهنمايى شغلى و كار آفرينى تلفيق شده در محتواى كتب درسى دوره متوسطه اول است. مشخصات مقاله

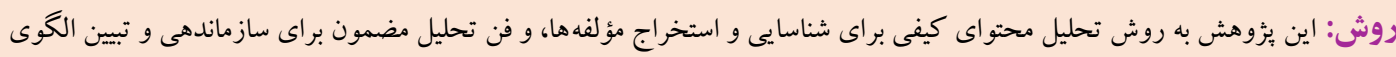

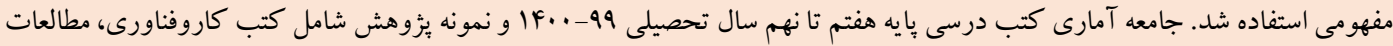

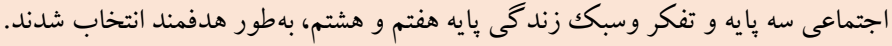

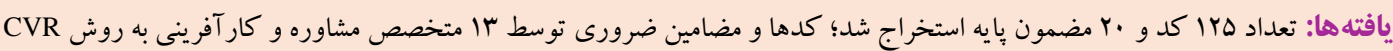

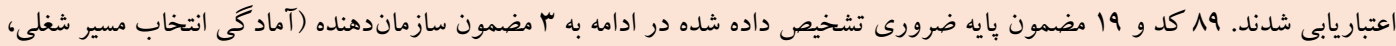

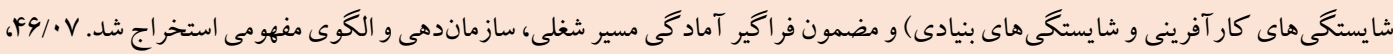

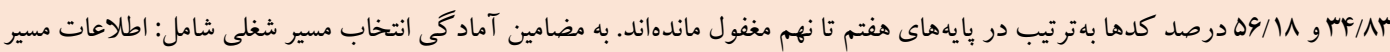

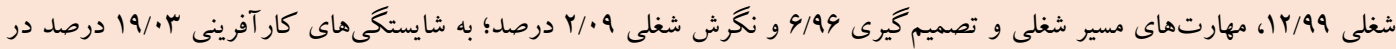
محتواى كتب درسى نمونه يزوهش توجه شده است.

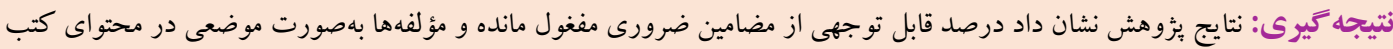

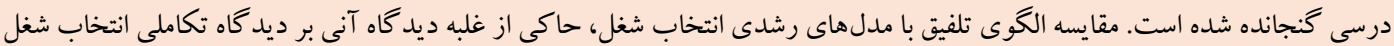


شايستكى هاى كار آفرينى معطوف به فرصت دادن به همه دانش آموزان

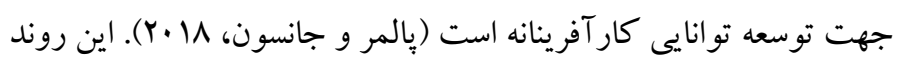
در تمام سطوح آموزشى ارويا قابل مشاهده است، نظامها و فر آيندهاى

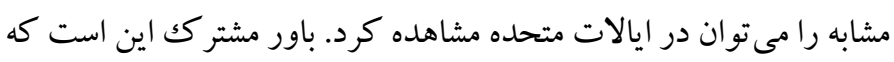

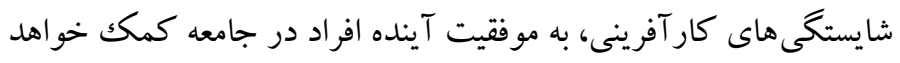

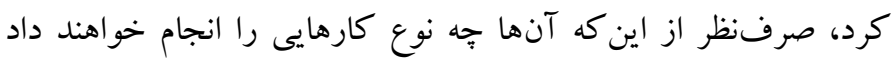

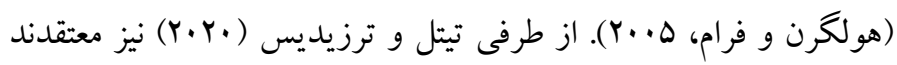

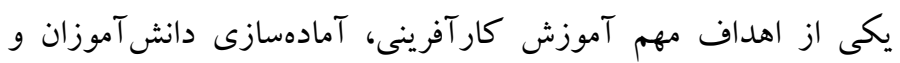

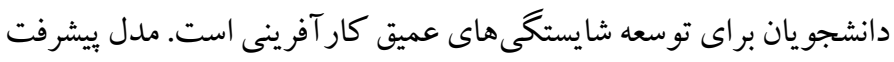

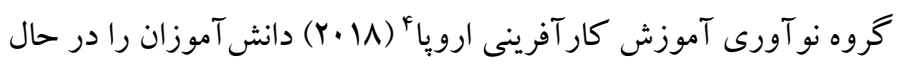

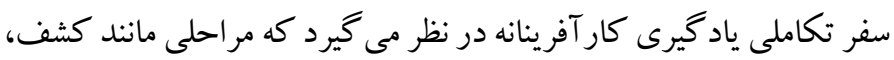
كاوش و آزمايش كردن را متناسب با سن و دوره تحصيلى مى كذار مارنند.

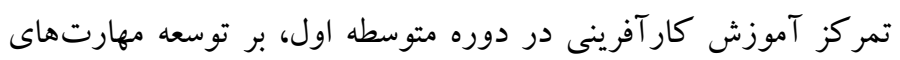

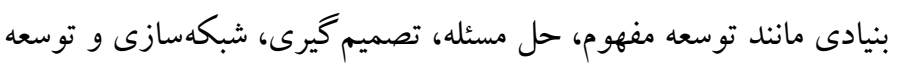
خلاقيت، فنون ايدهيردازى، حل خلاقانه مسائل نيز در كانون توجه بايد

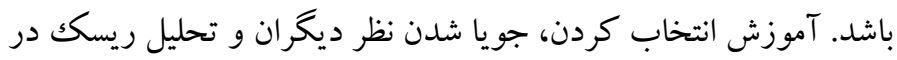
اين سن مهم است. بهنظر مىرسد مدل بيشرفت گروه نو آورى آموزش

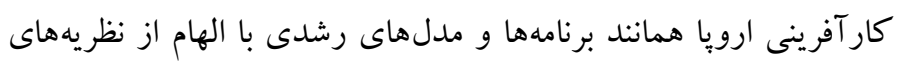
رشد شغلى، ضمن توجه به مراحل رشد، با انجام وظايف رشدى متناسب با

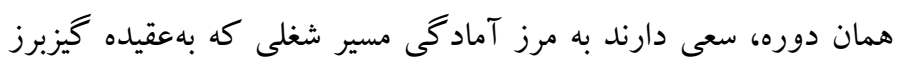

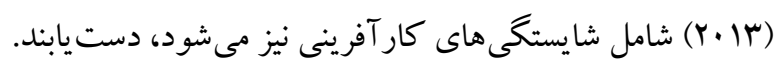

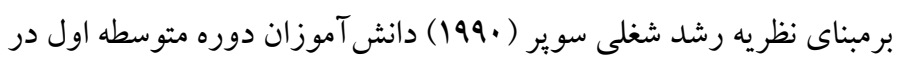

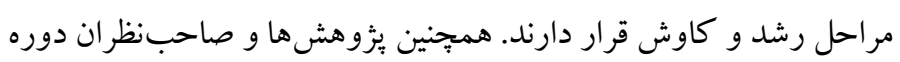

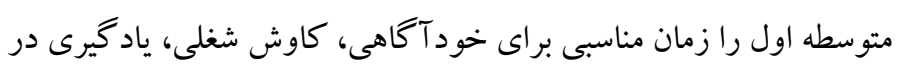

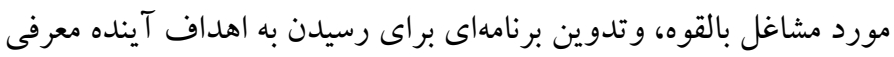

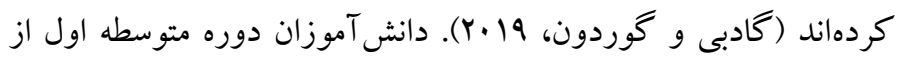

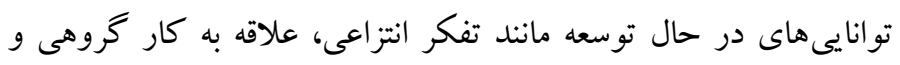

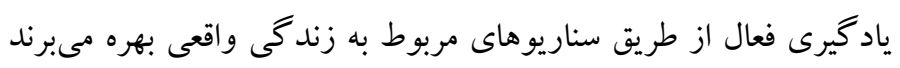

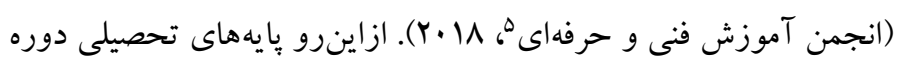

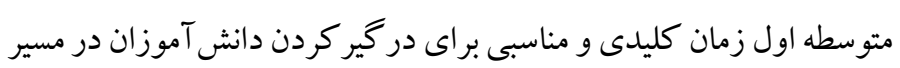

${ }^{4}$. entrepreneurial learning journey

5. ACTE
مقلفمه

بررسى ادبيات راهنمايى شغلى نشان مىدهد كه نويسند گان در سراسر جهان از واز كان متنوعى معادل راهنمايى و مشاوره شغلى استفاده كردهاند؛ به

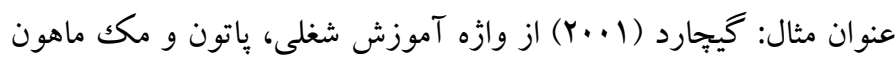

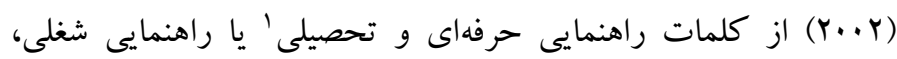

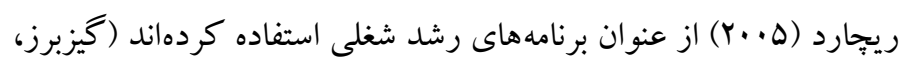

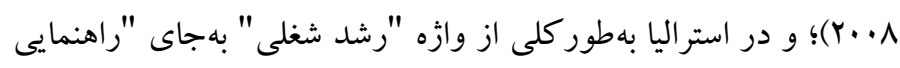

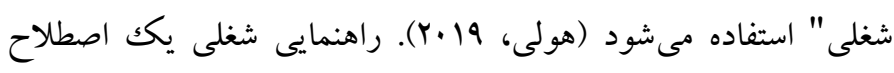

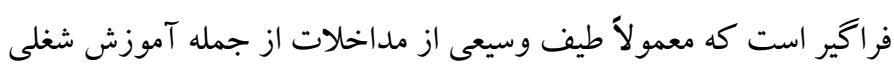

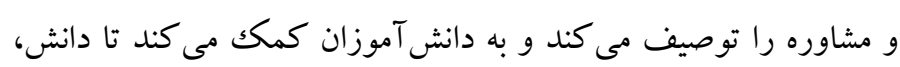

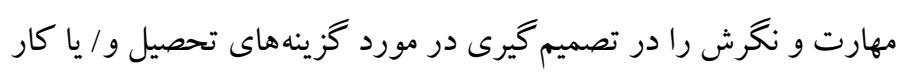

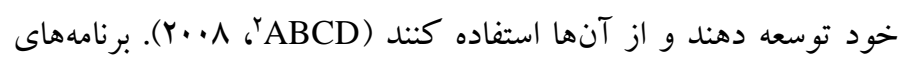

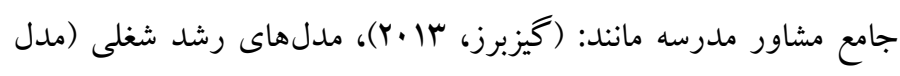

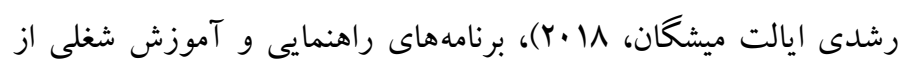

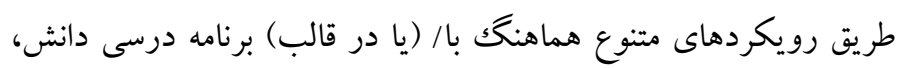

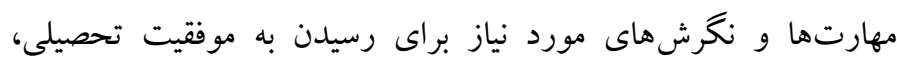
آمادگى تحصيلى و شغلى، و رشد عاطفى / اجتماعى دانش آموزان براى

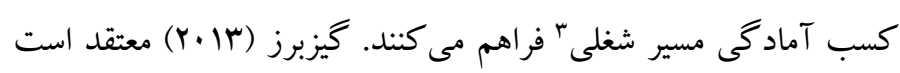

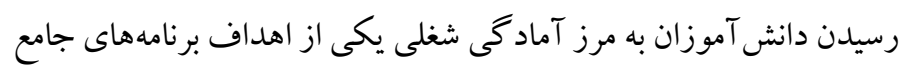
مشاور مدرسه است. رفتارها و مهارتهاى مورد نياز براى دستيابى به ماديه

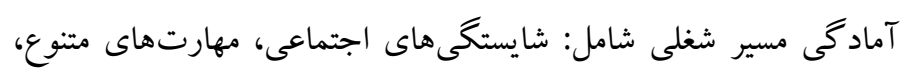

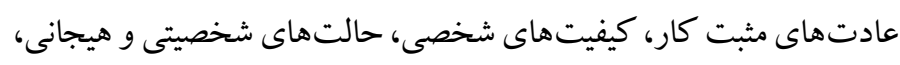
و كار آفرينى هستند. كار آفرينى بهعنوان يكى از شايستخىهاى كليدى براى دست يابى به

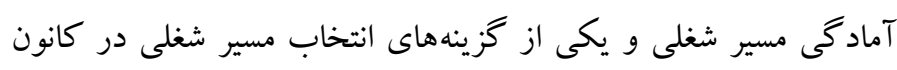

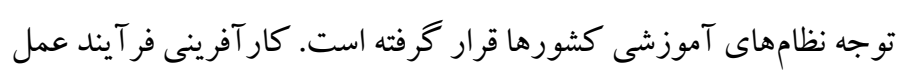

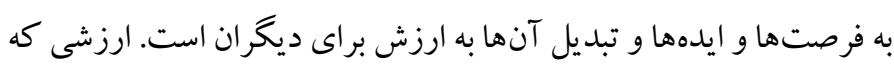

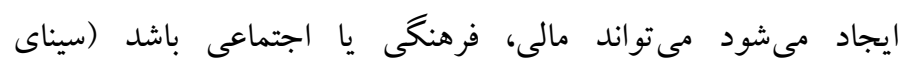

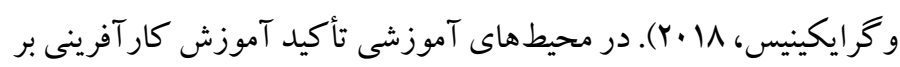

${ }^{1}$. educational and vocational guidance

2. Australian Blueprint for Career Development

3. career readiness 
بريجستاكك؛ گرانت ايمارو و مكك آليين (19) معتقدند تلفيق ياد گيرى توسعه مسير شغلى در برنامه درسى از اهميت قابل توجهى برخوردار ورت است.

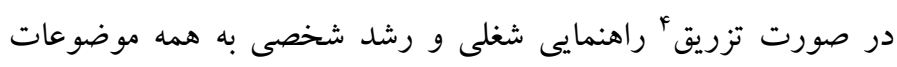

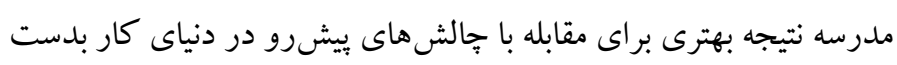

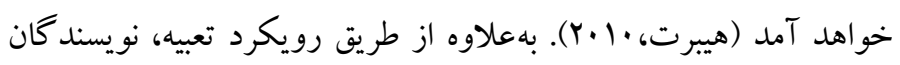
كتابهاى درسى مى توانند از معلمان در نقش تسهيل كننده براى ايجاد

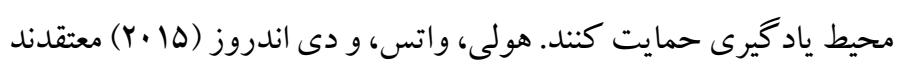

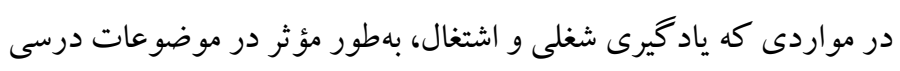

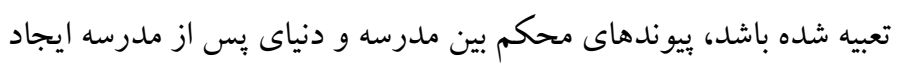
مىشود. يونسكو (Y.IV) آموزش براى توسعه بايدار در حالت: بهعنوان يكك (مدان

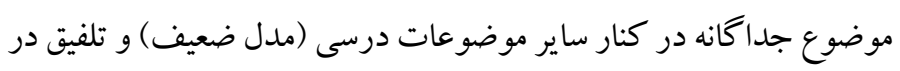
ساير موضوعات درسى (مدل قوى) ارزيابى كرده است. در بسيارى از كشورها، مدارس قادر به انتخاب يكى از اين مدلها هستند. هر مدل مو افقان

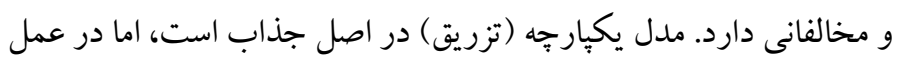

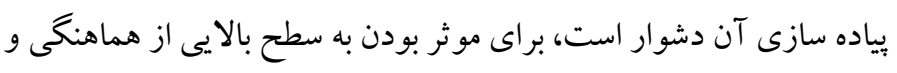

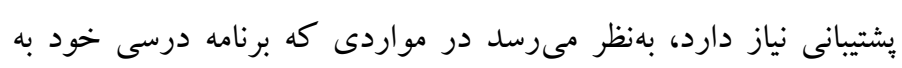

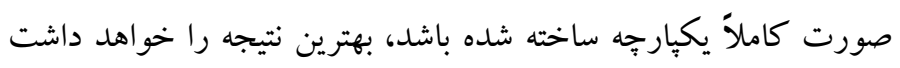

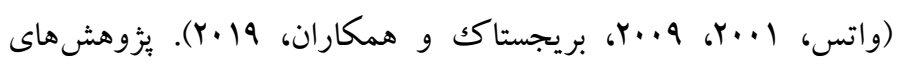
بيمايشى ضرورت تلفيق مداخلات آمادگى شغلى و تحصيلى در برنامه

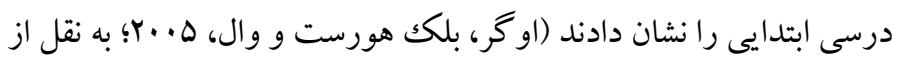

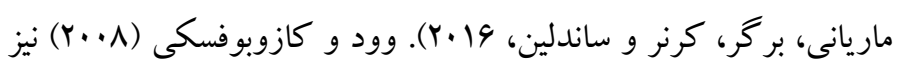
تلفيق آمادكى شغلى و تحصيلى رادر برنامه درسى سنتى ابتدايى را از طريق و كاني يكك برنامه راهبردى توسعه شغلى توصيه كردند. ازاينرو برنامه راهنمايى و

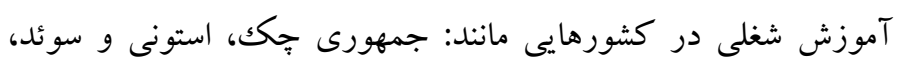
برنامهاى آموزش شغلى در بيشتر يا همه موضوعات درسى تزريق مى دى

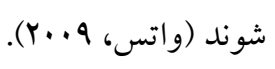

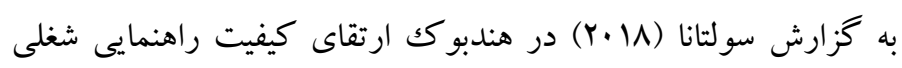
مدارس متوسطه اول، بسيارى از نظامهاى آموزشى در سطح بين المللى،

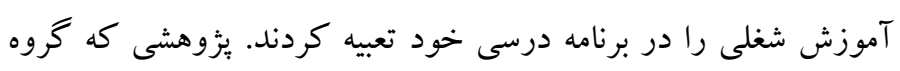

${ }^{3}$. transversal

${ }^{4}$. Infusion
آمادگى شغلى و تحصيلى است. بنابراين اجراى برنامههاى راهنمايى شغلى

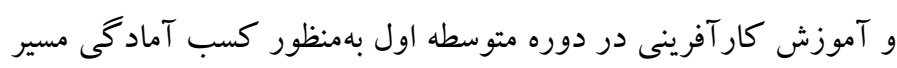

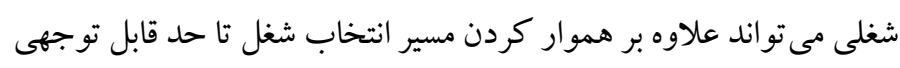

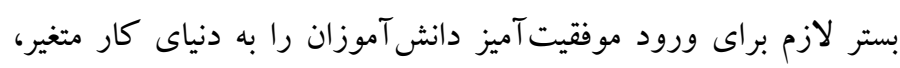

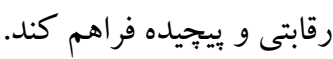

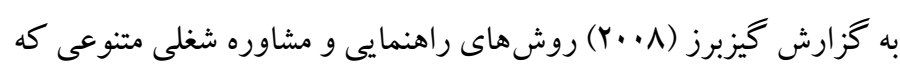
در كشورهاى مختلف استفاده مىشود شامل:

• برنامه هاى جامع راهنمايى و مشاوره (مانند: آمريكا و برخى (ايالتهاى كانادا)

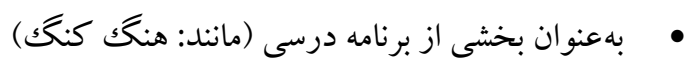

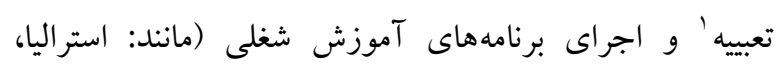

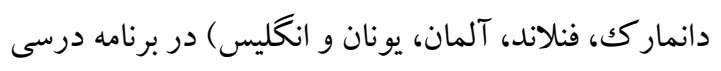

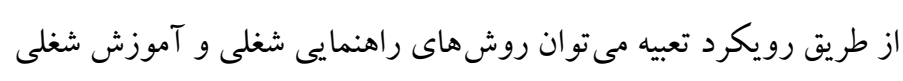
در قالب برنامه درسى گنجاند.

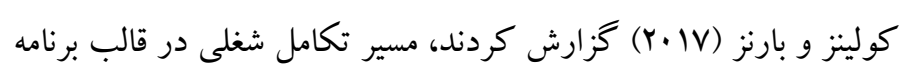
درسى ب به سه شيوه قابل اجرا است:

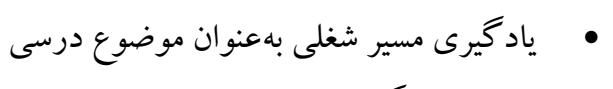

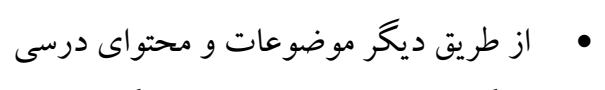

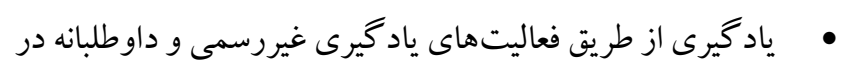
راستاى برنامه درسى

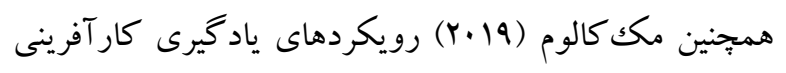

$$
\begin{aligned}
& \text { در برنامه درسى به سه روش كز ارش مى كند: } \\
& \text { • به عنوان يكك موضوع يا دوره جداكانه } \\
& \text { • • • •بهورت تلفيق در ديخر موضوعات يا دورهها }
\end{aligned}
$$

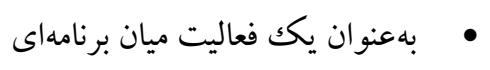

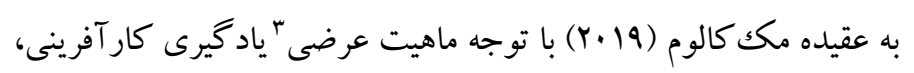
مى تواند در هر موضوع و در هر سطح از تحصيل برگزار شود. همجنين

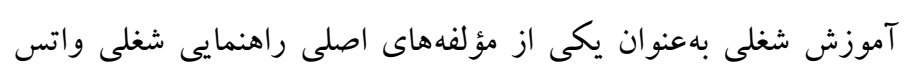

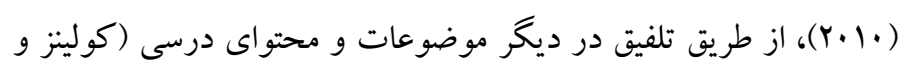
بارنز، (Y.IV) قابل تلفيق در برنامه درسى است.

1. embedding

${ }^{2}$. careers in the curriculum 
بازار كار كمكك كند. با اين حال و با توجه به ضرورت اتخاذ رويكرد

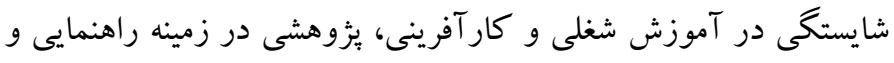

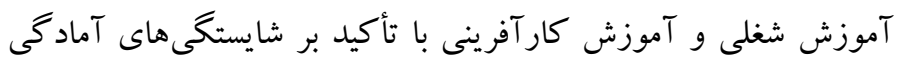

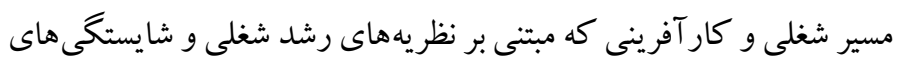
كار آفرينى در دوره ابتدايى و دوره متوسطه اول انجام نشده است.

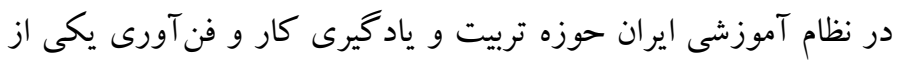

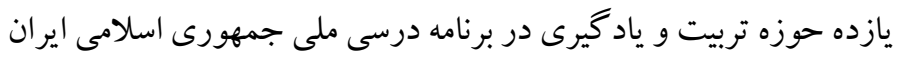

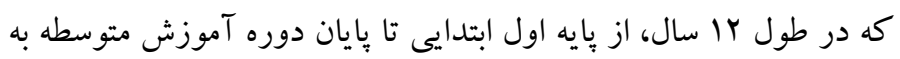

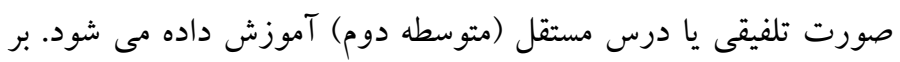

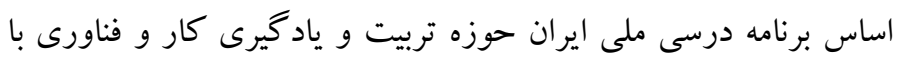
هدف كسب شايستخى كارهاى مورد نياز زندگى و دنياى كار طراحى و و

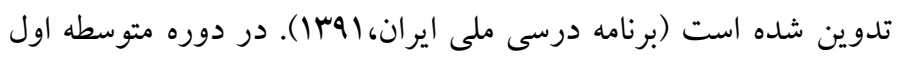
كسب شايستخىهاى كار آفرينى، فناورى اطلاعات، بلوغ حرفهاى إي، كار در

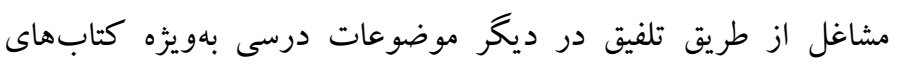

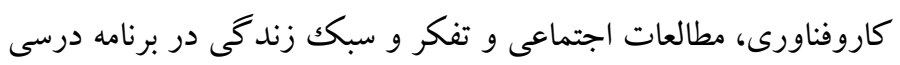
مورد توجه قرار گرفته است. اهميت حياتى موضوع آمادكى مسير شغلى دانش آموزان در ادامه موفقيت

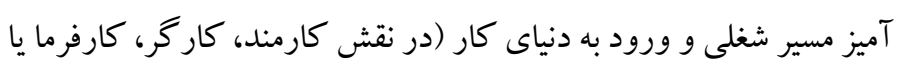

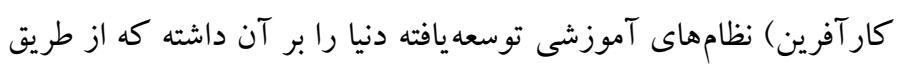
روشها و رويكردهاى متنوع يا تركيبى از آنها مانند: برنامههاى جامع و

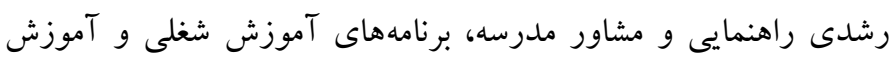

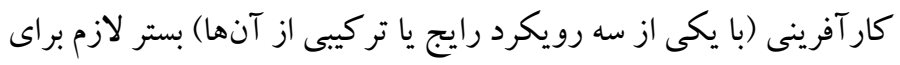

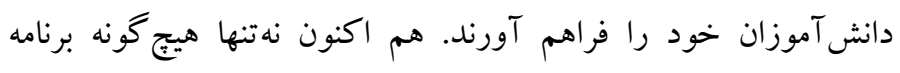

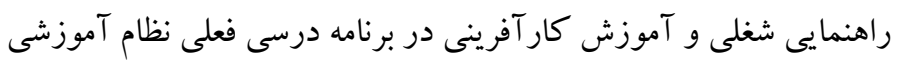
ايران در دوره ابتدايى و دوره متوسطه اول بهصورت مستقل وجود ندارد بلكه علىرغم حضور مشاوران در دوره متوسطه اول، خدمات راهنمايى و

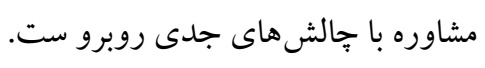

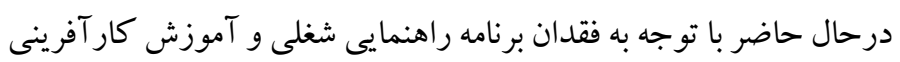
در دوره متوسطه اول ايران، آمادكىهاى لازم براى مسير شغلى دانش

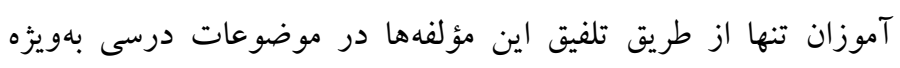
كاروفناورى، تفكر و مطالعات اجتماعى در حال انجام است. ازاينرو

2. incorporating
ايتاكا (Y.19) با بررسى تجارب بينالملى درمورد تلفيق راهنمايى و

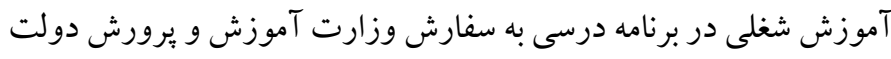

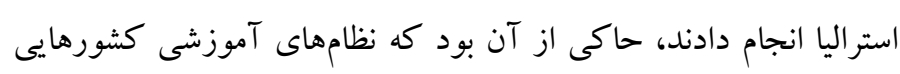

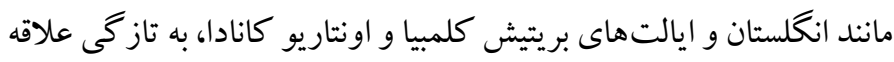
كستردهاى به رويكردهاى ميان برنامه درسى' نسبت به تلفيق راهنمايى و ولنئ

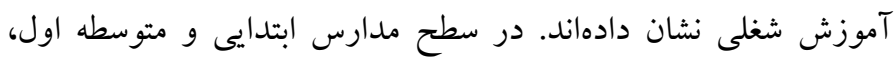

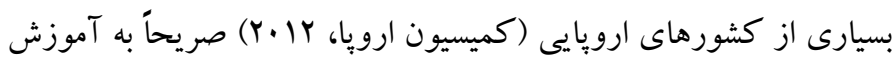

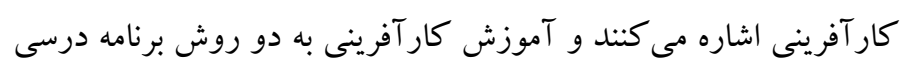

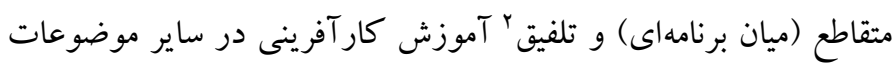

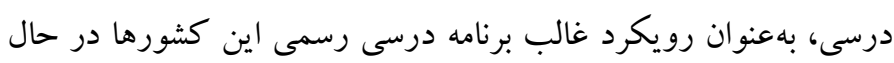

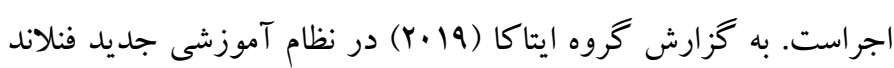

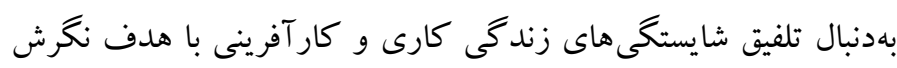
مثبت به كار و زندگى كارى در دوره ابتدايى و بالاتر هستند.

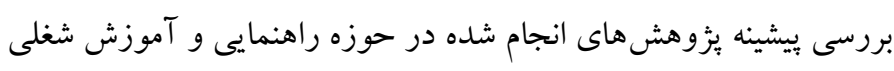

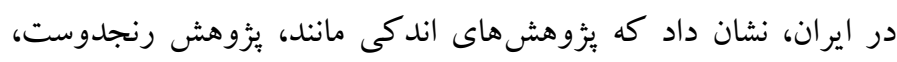

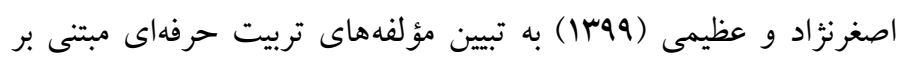
شايستخى و تحليل جايگاه آن در كتاب هاى درسى مربوط به شايستخى هاى غيرفنى دوره دوم متوسطه فنى و حرفهاى و كاردانش بردداختهاند و در دوره تهاب هاى ابتدايى، متوسطه اول و دوم يثوهشى در اين حوزه مشاهده نشد.

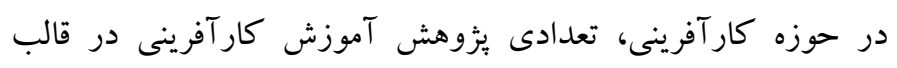

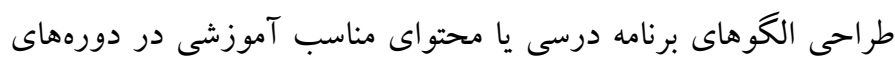

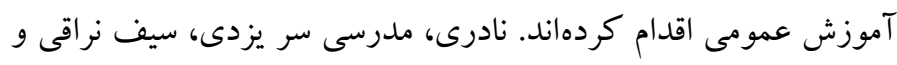

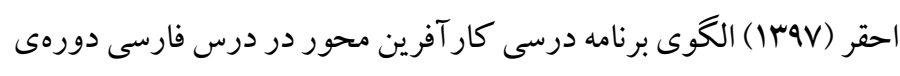
ابتدايى؛ عزيزى و مختارى (941) محتواى برنامه درسى كار آفرينى در

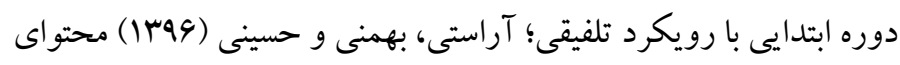

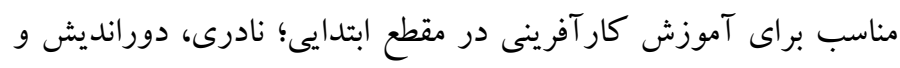

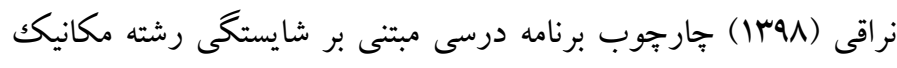
صنايع دوره دوم متوسطه اقدام كردهاند.

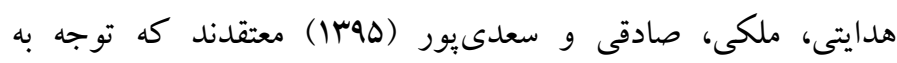
رويكردهايى مانند رويكرد شايستكى علاوه بر تشريح رابطه بين محيطهاى

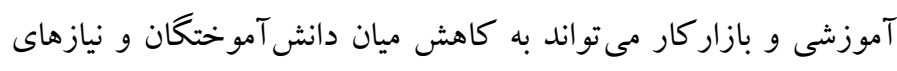

${ }^{1}$. cross-curricular approaches 
اول متوسطه و در بخش خبر گان شامل متخصصان مشاوره، برنامهريزى درسى و كار آفرينى بودند.

نمونه بززوهش در بخش تحليل محتو ایى كتب درسى شامل كتابهاى كار

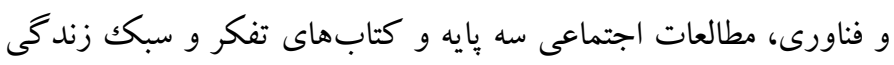

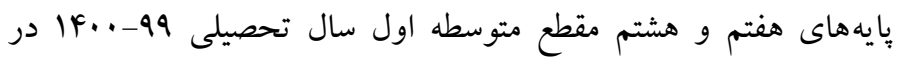
مجموع (1 جلد كتاب) كه بيشترين ارتباط را بهلحاظ اهداف و محتوا، فعاليتهاى ياد گيرى و ارزشيابى با مؤلفهاى راهنمايى شغلى و كار آفرينى

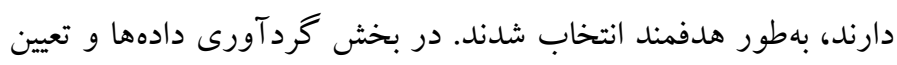

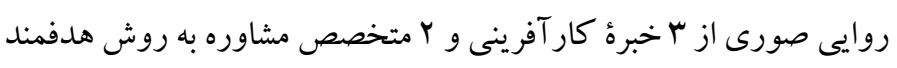

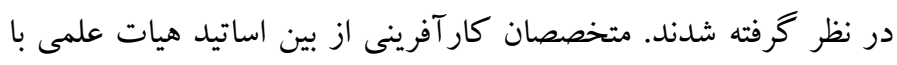
حداقل درجه علمى استاديارى داراى سوابق آموزش و يثزوهش در زمينه كار آفرينى؛ و متخصصان مشاوره داراى حداقل مدر كى دكترى با بيش از

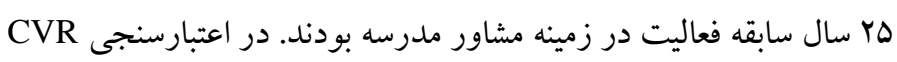
در مجموع از نظرات سا متخصص حوزه مشاوره و كار آفرينى استفاده شد. متخصصان حوزه مشاوره از بين فارغالتحصيلان رشته مشاوره با داشتن حداقل ه سال سابقه تدريس در دانشگاه يا فعاليت هاى حوزه مشاوره مدرسه با داشتن حداقل مدر كك دكترى؛ در رشتههاى برنامهريزى درسى و مديريت

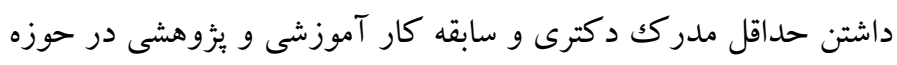

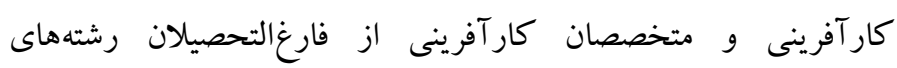

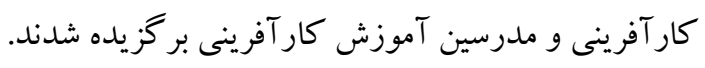

ب) ابزار براى گردآورى اطلاعات از محتواى كتب درسى از كاربرگكهاى تحليل

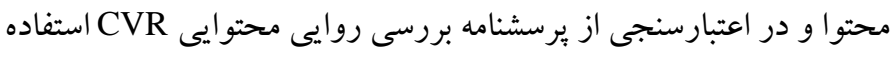

بهمنظور تهيه فهرست كامل تر، با ارائه فهرست كدها و مضامين مستخرج از

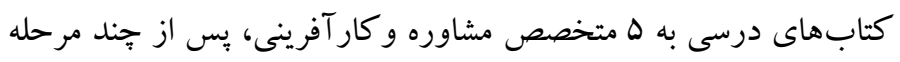
رفت و بر گشت بدون حذف كد يا مضمون، فهرست بيشنهادى تكميل شد.

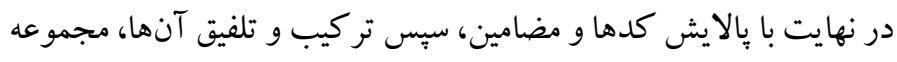

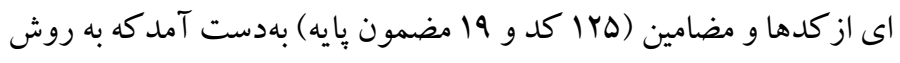

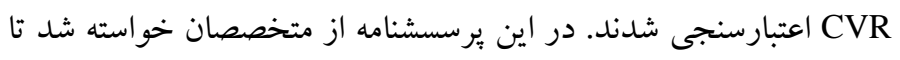

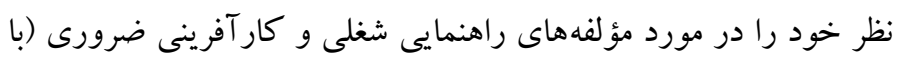

كشف و استخراج الكوى مفهومى مؤلفهاى راهنمايى شغلى و كار آفرينى

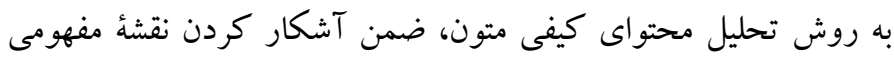

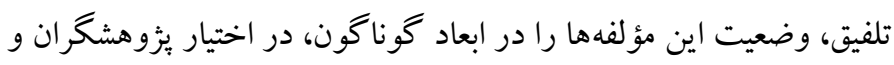
ذى نفعان (متخصصان مشاوره مدرسه و شغلى، برنامهريزان درسى و و

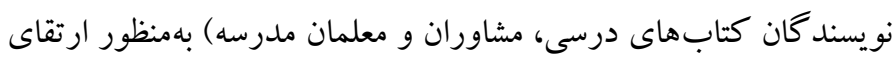

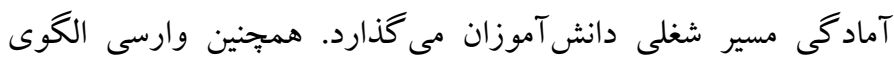

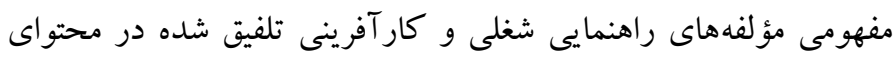

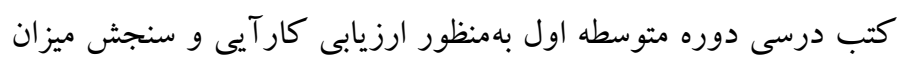

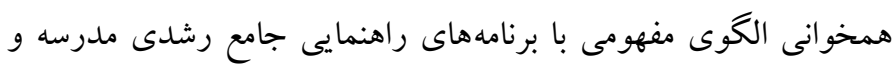

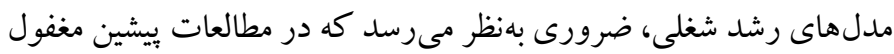
مانده است. در همين راستا در يثروش حاضر اين سؤ الها مطرح مى شود كه در محتواى

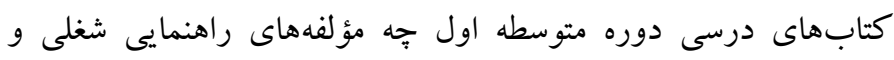

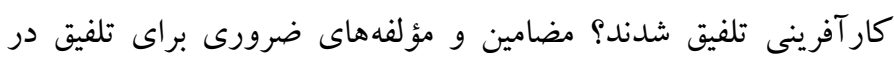

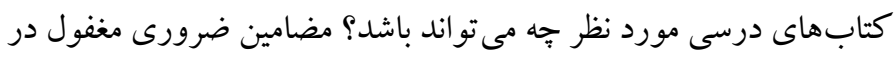

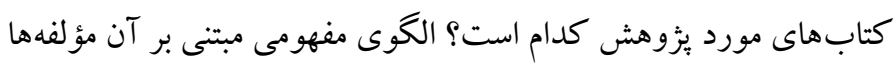

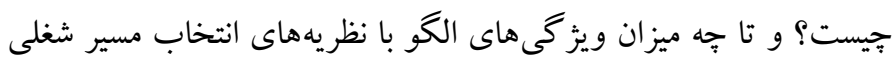

همخوان است؟

روش الف) طرح بئوهش و شر كت كنند كان: يثزوهش حاضر به روش تحليل

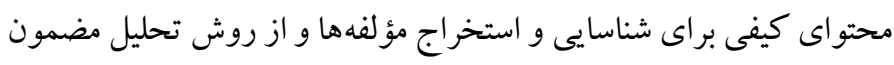

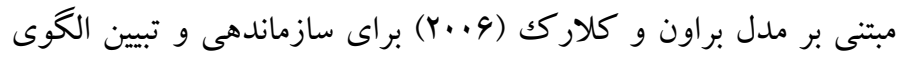

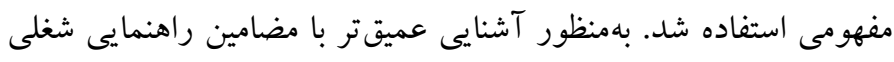

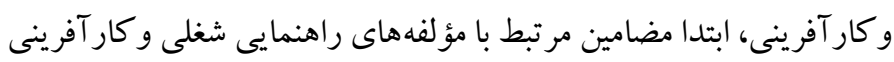

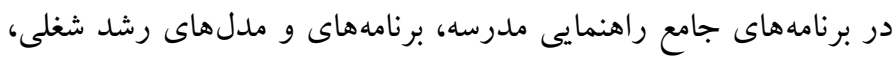

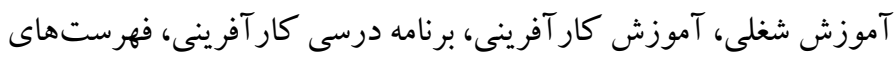

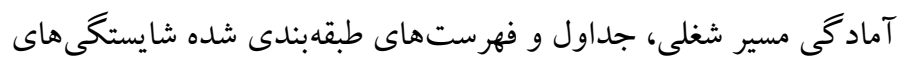

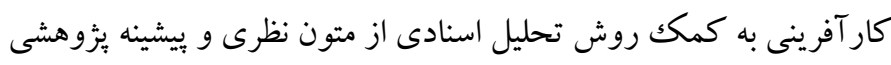

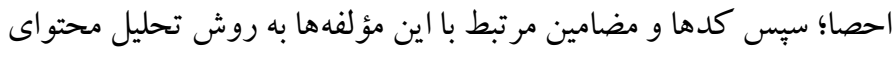
كيفى كتب درسى نمونه بزوهش، شناسايى و در كاربر گكهاى تحليل محتوا ثبت شدند. جامعه آمارى در بخش تحليل محتوا، كتابهاى درسى دورهئ دوره 
كام جهارم: بس از استخراج مضامين هركتاب درسى، مجموع مضامين مستخرج از كتب درسى نمونه بثوهش و مضامين مستخرج از متون همراه

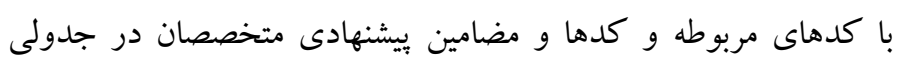
كرد آورى شدند، به لحاظ واقعى بودن مضمون بيشنهادى (حذف مض مضامين

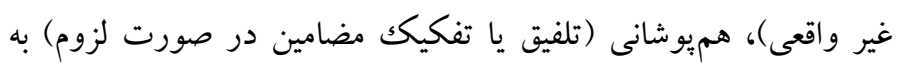

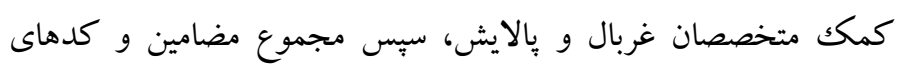
مربوطه در جدولى گردآورى و فهرست شدند.

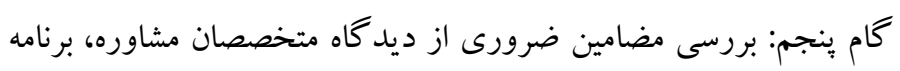

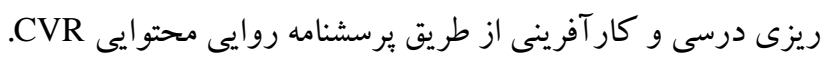

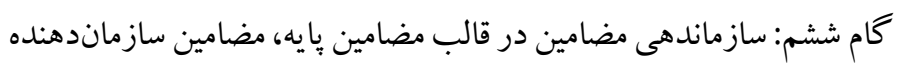
و فراگير به صورت جدولى و تدوين الكوى مفهومى مؤلفه هاى راهنمايى مضاني شغلى و كار آفرينى. كام هفتم: توصيف آمارى مضامين بهصورت نمودارهاى ستونى، تبيين

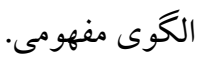

استفاده از روش تحليل مضمون در سازماندهى كدها و مضامين بايه، سازماندهنده و فراكير، ضمن آشكار كردن مضامين آشكار و نهان مؤلفه وفانه هاى راهنمايى و كار آفرينى، امكان تجزيه و تحليل، توصيف و تفسير كيفى

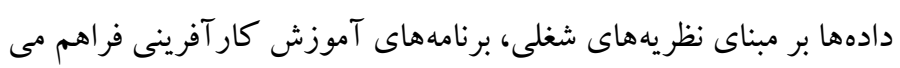

يس از شناسايى كدها و مضامين بايه، ميزان توافق متخصصان به روش

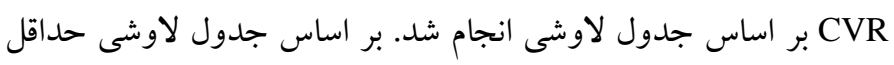

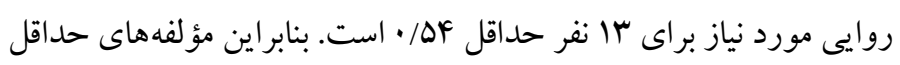

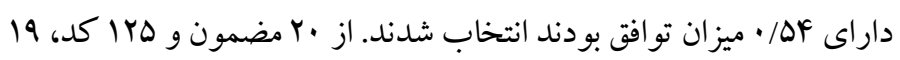

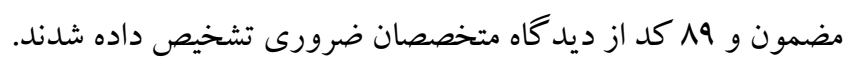

يافته ها در جدول ا نمونههايى از مصاديق (جمله، باراگراف، مضمون، فعاليت،

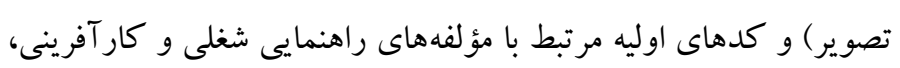

$$
\text { مستخرج از محتواى كتب درسى آمده است. }
$$

تأكيد بر آمادگى هاى مسير شغلى و شايستخى هاى كار آفرينى) براى تلفيق

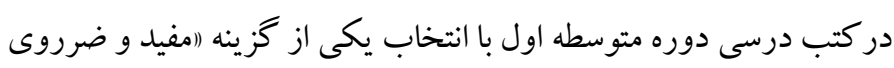

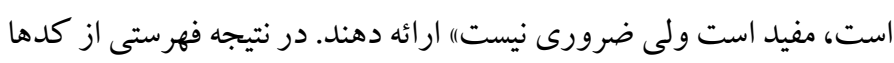

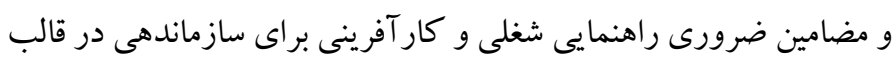

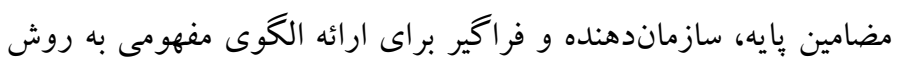

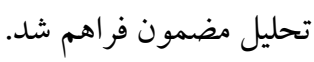

كامهاى اجراى تحليل مضمون كتب درسى و استخر اج الكوى مفهومى:

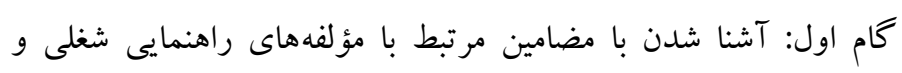

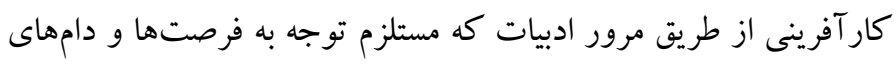
ناشى از مرور ادبيات در فر آيند تحقيق است.

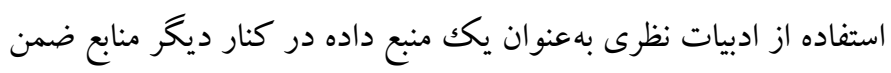

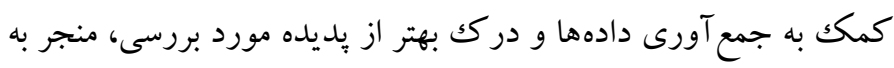

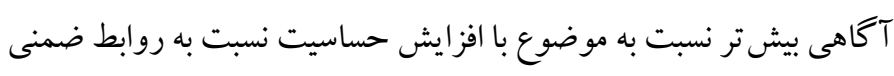

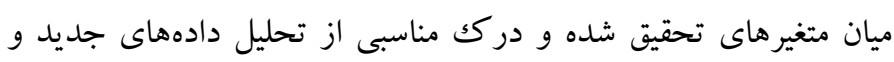

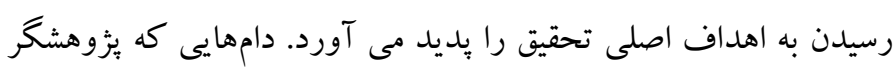

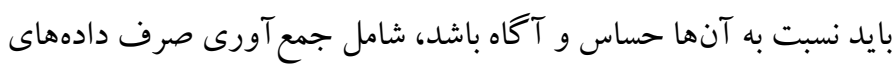
مرتبط با ادبيات نظرى؛ ممانعت از عرضه ايدههاى جديد و تحميل

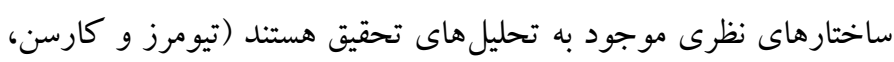

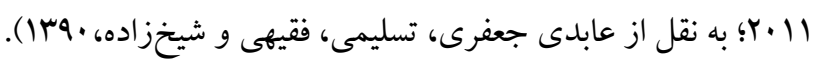

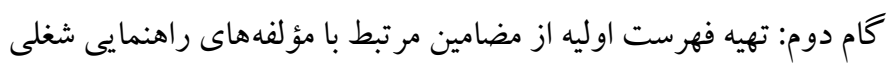
و كار آفرينى درقالب واحدهاى تحليل (جمله، پاراگراف، تصوير و ويا تكليف) از طريق بررسى محتوى تمام صفحات كتب درسى نمونه بزوهش دره

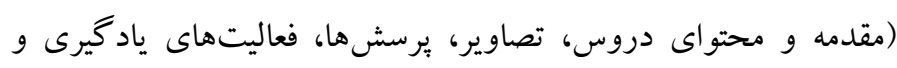

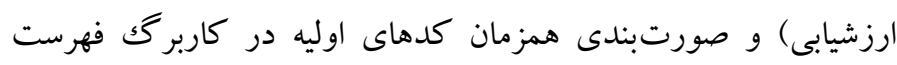
وارسى و ثبت فراوانى هر كد (بهصورت جدول سه ستونه حاوى مصاديق، كد اوليه و فراوانى)

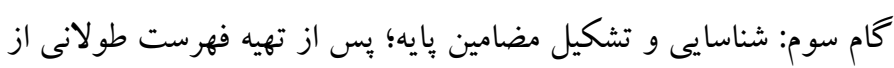
كدهاى مختلف و تجزيه و تحليل كدهاى اوليه مختلف و با در نظر كرفتن

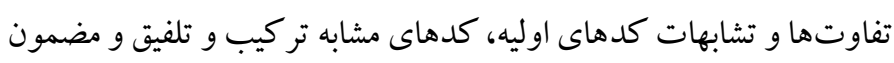

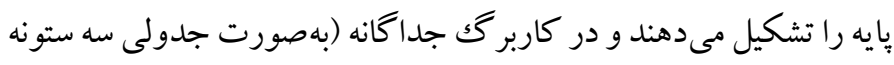
شامل كد اوليه، فراوانى، مضمون بايه) ثبت شد. 
جدول ا. نمونه مصاديق و كدهاى اوليه

\begin{tabular}{|c|c|}
\hline كد (مضمون فرعى) & مصاديق (جمله، باراكراف، مضمون، فعاليت، تصوير ) \\
\hline آشنايى با مشاغل و فرصت هاى شغلى & 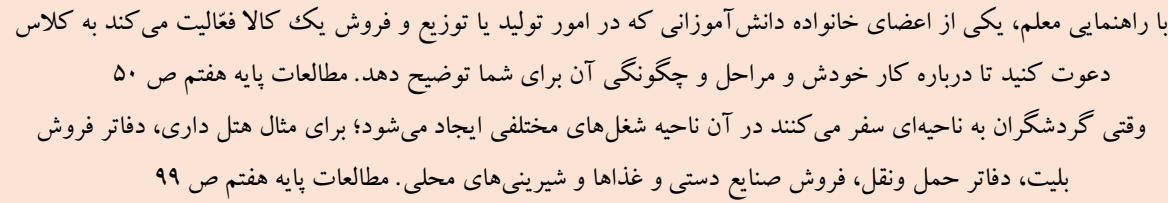 \\
\hline 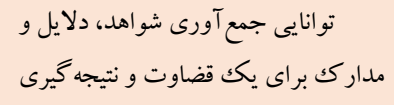 & جداول خود ارزيابى (قضاوت در مورد عملكرد خود با ارائه و ثبت دلايل و مستندات در جدول) كاروفناورى بايه هشتم ص 9ه \\
\hline مهارتهاى خود آكاهى مسير شغلى & آيا تاكنون به د لبستخىها، توانايىها و مهارتهاى خود در زمينه كار آينده انديشيدايد؟ كاروفناورى بايه هفتم ص DF \\
\hline
\end{tabular}

ها كد، مجموعهاى از ·r مضمون بايه بهدست آمدكه به روش CVR اعتبارسنجى شدند. بهدليل طولانى بودن فهرست كامل مؤلفه هاى راهنمايى شغلى و كار آفرينى تأييد شده توسط متخصصان، تعدادى از آنها، ميزان توافق، وضعيت (تأييد يا عدم تأييد) در جدول ب آمده است. مطابق جدول لاوشى حداقل روايى مورد نياز براى سا نفر حداقل DF/ • است.
تعداد 94 كد (مضمون فرعى) راهنمايى شغلى و كار آفرينى تلفيق شده در محتو اى كتابهاى درسى از طريق تحليل محتواى كيفى كتابهاى نمونه يثوهش شناسايى و استخراج شدند، كه در جدول r آمده است. به فهرست استخراج شده از محتواى كتابهاى درسى با ارائه به ه متخصص مشاوره و كار آفرينى، يس از جند مرحله رفت و بر گشت بدون حذف كدهاى مو جود، مضامين جديدى افزوده و با هY كد تكميل شد. با تر كيب و تلفيق

جدول ז. كدهاى مستخرج از محتواى كتابهاى درسى نمونه يثوهش

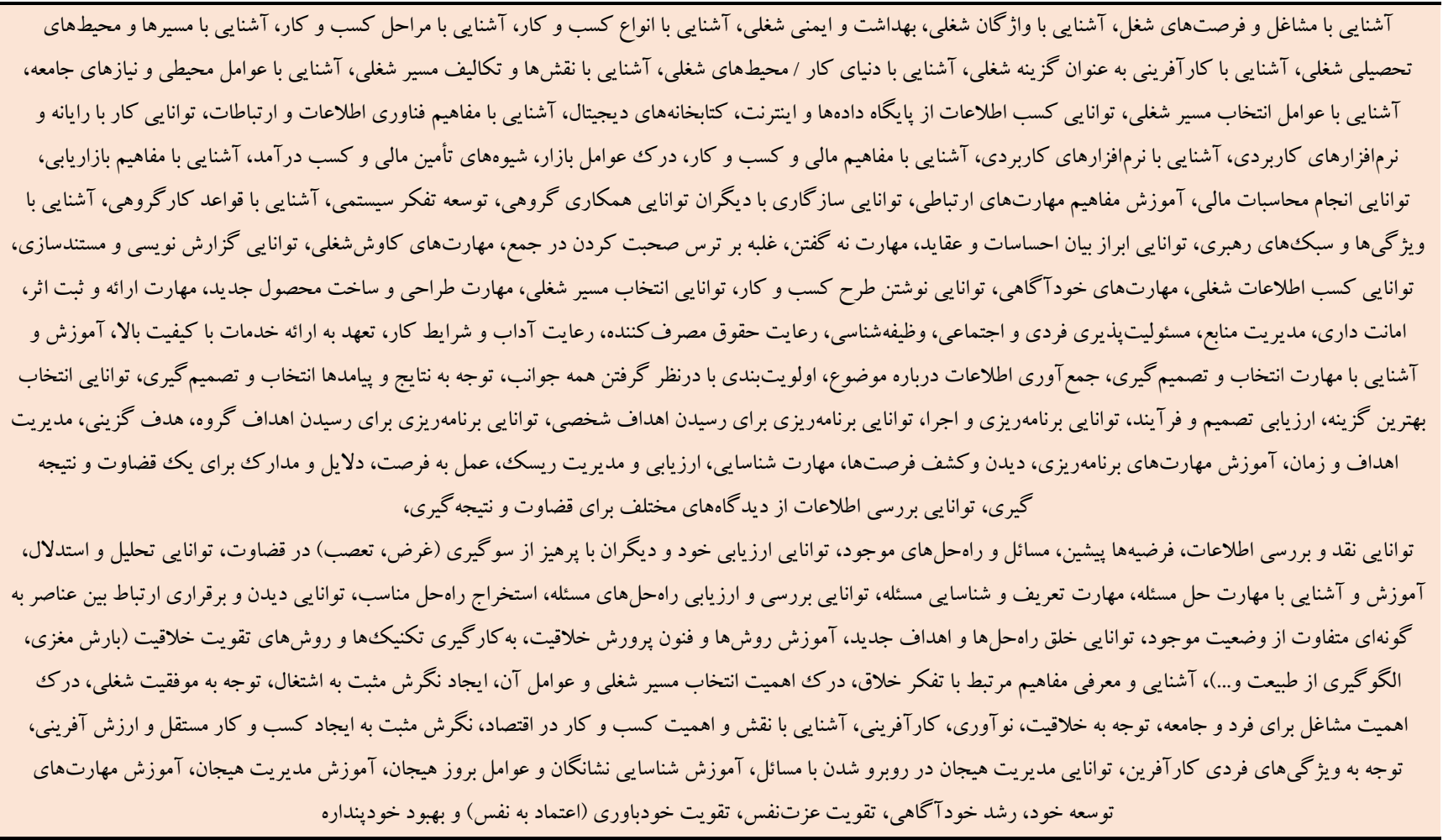


جدولّا. مؤلفه هاى راهنمايى شغلى و كار آفرينى و ميزان توافق متخصصان

\begin{tabular}{|c|c|c|c|}
\hline \multicolumn{2}{|c|}{ وضعيت } & \multirow{2}{*}{ 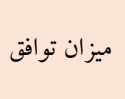 } & \multirow{2}{*}{ مؤلفههاى راهنمايى شغلى و كار آفرينى } \\
\hline عدم تأييد & تأييد & & \\
\hline \multirow{3}{*}{$*$} & \% &.$/ 99$ & آشنايى با واز گان (شغلى، كار آفرينى و مفاهيم مر تبط) \\
\hline & & 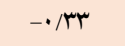 & آشنايى و معرفى ابزار سنجش شغلى \\
\hline & $\%$ &.$/ 99$ & آشنايى با مسيرها و محيطهاى تحصيلى شغلى \\
\hline \multirow{7}{*}{ * } & $\%$ & - /AF & آشنايى با كار آفرينى بهعنوان يك گزينه شغلى \\
\hline & $*$ & - /AF & آشنايى با دنياى كار / محيطهاى شغلى \\
\hline & $*$ & $\cdot / A F$ & آشنايى با مشاغل و فرصتهاى شغلى \\
\hline & & r & آشنايى با قوانين، ايمنى و بهداشت محيط كار \\
\hline & * & $\cdot / A F$ & آشنايى با انواع كسب و كار \\
\hline & $*$ & $\cdot / \Delta F$ & آشنايى با مر احل كسب و كار \\
\hline & $*$ & $\cdot / \wedge F$ & آشنايى با انواع كسب و كار \\
\hline \multirow{3}{*}{$*$} & * & $\cdot / \Delta F$ & آشنايى با مراحل كسب و كار \\
\hline & & $\cdot / T V$ & آشنايى با نقشها و تكاليف مسير شغلى \\
\hline & $\%$ & $\cdot / 94$ & آشنايى باعوامل محيطى و نيازهاى جامعه در انتخاب رشته تحصيلى شغلى \\
\hline \multirow{3}{*}{ * } & $*$ & $\cdot / \wedge 1$ & آشنايى باعوامل فردى در طرحريزى مسير شغلى \\
\hline & & $\cdot /$ / & آشنايى با نرمافزارهاى كاربردى، بايگاه دادهها و اينترنت، كتابخانههاى ديجيتال، رايانه \\
\hline & * & $\cdot / \Delta F$ & تو انايى كار با رايانه و نرم افزارهاى كاربردى \\
\hline * & & $\cdot / \mu$ & آشنايى با مفاهيم و ابزار فناورى اطلاعات و ارتباطات \\
\hline
\end{tabular}

هاى آماد گى مسير شغلى به عنو ان مضمون فر اخير طبقهبندى شدند. الخوى

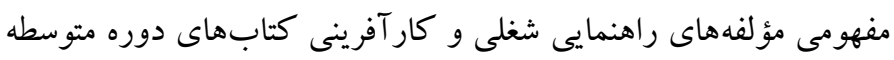

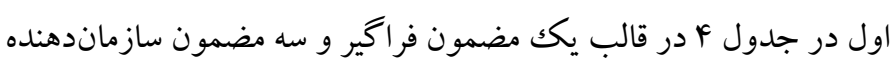

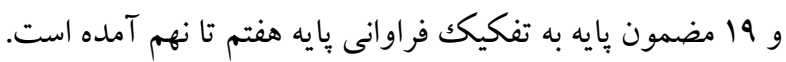

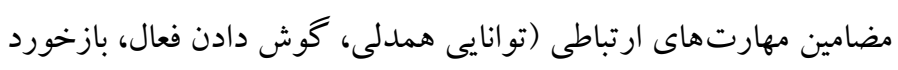

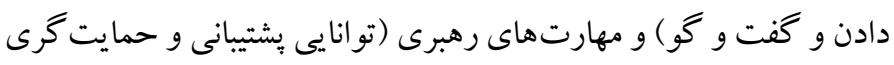

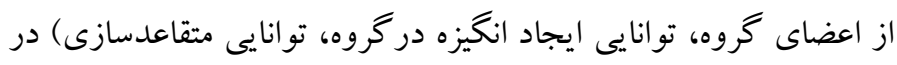

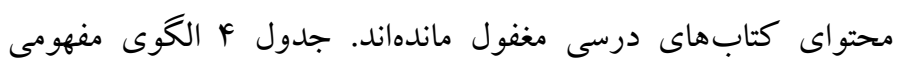

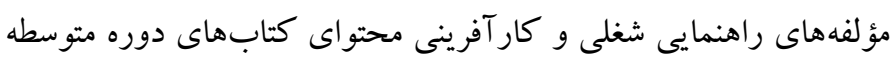
اول را نشان مى دهند. جدول ه، ضمن توصيف كلى مضامين سازماندهنده راهنمايى شغلى و

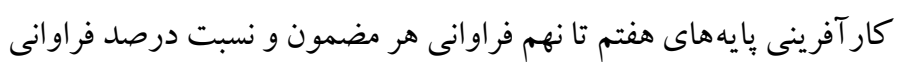
آن مضمون به فراوانى را بيان مى كند.
از مجموع هr كا كد، تعداد وץ كد و تنها يكك مضمون يايه (مهارتهاى

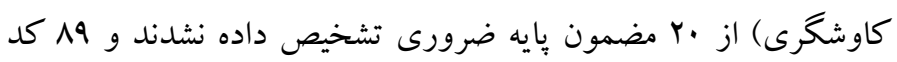

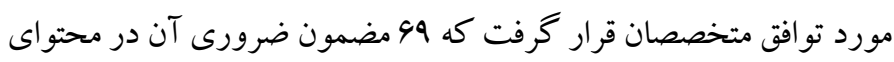

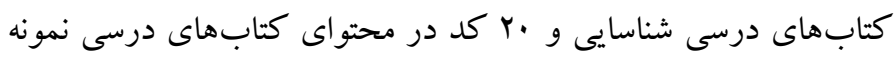
يُزوهش مغفول ماندهاند. با تجزيه و تحليل كدها، سبس تركيب و تلفيق مهده كد استخراجشده 19 مضمون بِايه (اطلاعات مسير شغلى، سواد فناورى اطلاعات و ارتباطات،

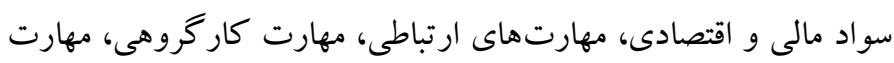

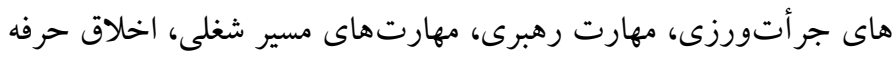

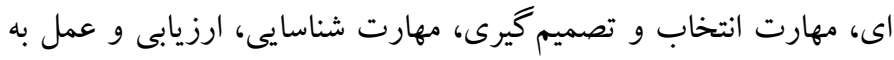

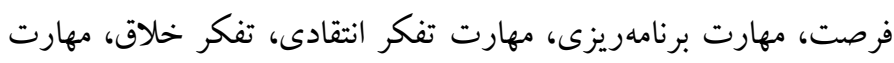

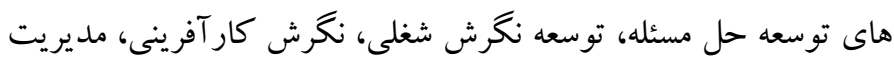

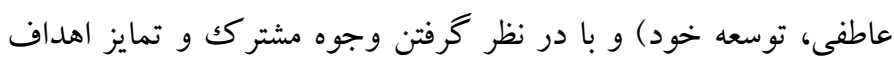

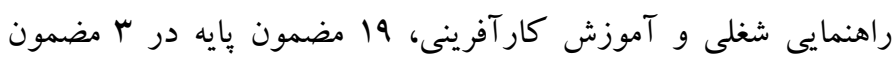

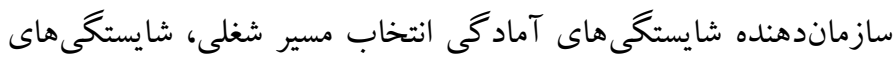

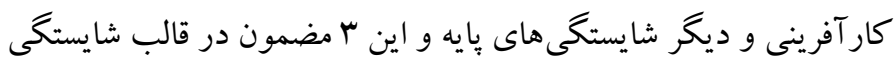


جدول ع. الكوى مفهومى مؤلفه هاى راهنمايى شغلى و كار آفرينى كتابهاى دوره متوسطه اول

\begin{tabular}{|c|c|c|c|c|c|c|}
\hline \multicolumn{7}{|c|}{ شايستخىهاى آماد گى مسير شغلى (مضمون فراگير) } \\
\hline \multirow{2}{*}{ 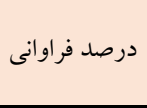 } & \multirow{2}{*}{ فراوانى كل } & \multicolumn{3}{|c|}{ فراوانى } & \multirow{2}{*}{ مضامين بايه } & \multirow{2}{*}{ مضامين سازماندهنده } \\
\hline & & 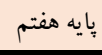 & بايه هشتم & بحايه نهم & & \\
\hline$\% 1 \% / 99$ & $11 \%$ & kr & YF & $f \Delta$ & اطلاعات مسير شغلى & شايستخى هاى \\
\hline$\% / F / 4$ & ra & $\wedge$ & 9 & ri & مهارتهاى مسير شغلى & آمادگى انتخاب \\
\hline$\% / \Delta / \Delta \Delta$ & rr & . & rI & 1 & مهارت انتخاب و تصميم گيرى & مسير \\
\hline$\% / r / \cdot 9$ & 11 & r & $\wedge$ & $\checkmark$ & نغرش شغلى & 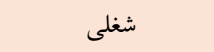 \\
\hline$\%$ F/VG & 41 & rV & $v$ & $\checkmark$ & سواد مالى و اقتصادى & \\
\hline \% & WV & rr & rA & iv & مهارت تفكر خلاق & شايستخى هاى \\
\hline$\% \cdot / \Delta \wedge$ & $\Delta$ & $r$ & 1 & 1 & مهارت شناسايى فرصت & كار آفرينى \\
\hline$\% F / V q$ & 4i & 19 & iv & $\wedge$ & نخرش كار آفرينى & \\
\hline$\% / 9 / \mathrm{r}$ & $\Delta \Delta$ & ro & 19 & if & سو اد فناورى اطلاعات و ارتباطات & \\
\hline$\% / \Delta / \mu F$ & 49 & ri & 19 & 9 & مهارت تفكر انتقادى & \\
\hline$\%$ & rq & ir & 9 & $v$ & مهارت حل مسئله & \\
\hline 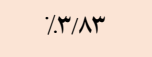 & r & $v$ & 11 & 10 & مهارت برنامهريزى & \\
\hline$\% \cdot / \cdot$ & . & $\cdot$ & $\cdot$ & . & مهارت هاى ارتباطى & شايستخى هاى بنيادى \\
\hline$\% \mathrm{~V} / \mathrm{VV}$ & $9 \mathrm{~V}$ & 山 & $r r$ & v & مهارتهاى كار گروهى & آمادگ \\
\hline$\% / \cdot$ & $\cdot$ & · & · & · & مهارتهاى رهبرى & مسير شغلى \\
\hline$\% 9 / 01$ & Nr & f. & r & 19 & مهارتهاى جرات ورزى & \\
\hline$\% / \Delta r$ & rq & ir & rV & . & مديريت عاطفى & \\
\hline$\% / \mathrm{V} / \mathrm{I}$ & ar & mr & ru & $r$ & توسعه خود & \\
\hline$\% 1 \cdot / 9$. & af & rr & re & ro & اخلاق حرفهاى & \\
\hline$\% 1 . \cdot \cdot$ & NGY & ror & $r \cdot r$ & r.9 & 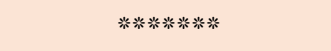 & مجموع فراوانى \\
\hline
\end{tabular}

\begin{tabular}{|c|c|c|c|c|c|c|}
\hline درصد فراوانى & فراوانى كل & پپايه هفتم & קֶايه هشتم & بايه نهم & مضامين سازماندهنده & \\
\hline$\% r Y / \cdot F$ & 19. & $\Delta F$ & $4 r$ & $v^{k}$ & شايستخى هاى آمادگى انتخاب مسير شغلى & \multirow{3}{*}{ شايستخى هاى آمادگى } \\
\hline$\% 19 / \cdot r$ & 194 & vı & $\Delta r$ & r & شايستخى هاى كار آفرينى & \\
\hline$\%$ \%N/q & $\Delta \cdot \Lambda$ & rrI & $M$ & 99 & شايستخىهاى بنيادى آمادگى مسير شغلى & \\
\hline$\% 1 \cdot \cdot / \cdot$ & Nar & ror & $r \cdot r$ & $r \cdot 9$ & 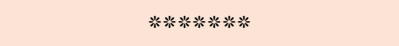 & مجموع \\
\hline
\end{tabular}

\begin{tabular}{ccccccc}
\multicolumn{7}{c}{} \\
\hline
\end{tabular}




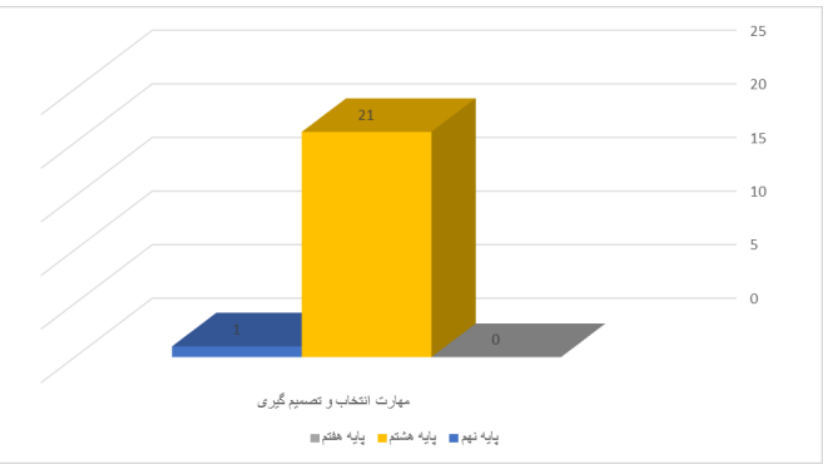

نمودار ז. توزيع فراوانى مضمون مهارت انتخاب و تصميم يرى بدى

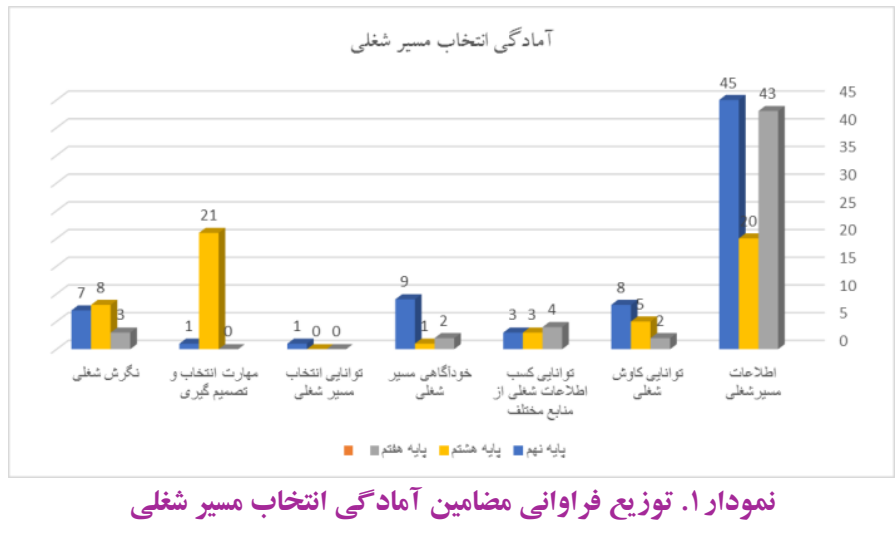

جدول V. شايستغى هاى كار آفرينى كتابهاى دوره متوسطه اول

\begin{tabular}{|c|c|c|c|c|c|c|}
\hline \multirow{2}{*}{ درصد فراوانى } & \multirow{2}{*}{ فراوانى كل } & \multicolumn{3}{|c|}{ فر اوانى } & \multirow{2}{*}{ مضامين يايه } & \multirow{2}{*}{ ضضمون سازماندهنده } \\
\hline & & بايه هفتم & يايه هشتم & بايه نهم & & \\
\hline$\% \& / V q$ & 41 & rV & $v$ & $v$ & سو اد مالى و اقتصادى & \\
\hline \% /N/ar & w & rr & ru & iv & مهارت تفكر خلاق & شايستخى هاى \\
\hline$\% \cdot / \Delta \Lambda$ & $\Delta$ & $r$ & 1 & 1 & مهارت شناسايى فرصت & كار آفرينى \\
\hline$\% \& / V q$ & Fi & 19 & IV & $\wedge$ & نخرش كار آفرينى & \\
\hline$\% 19 / \cdot r$ & 194 & $\mathrm{vA}$ & $\Delta r$ & r & 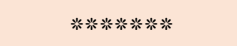 & مجموع فراوانى \\
\hline
\end{tabular}

$$
\text { شايستكى هاى كار آفرينى }
$$

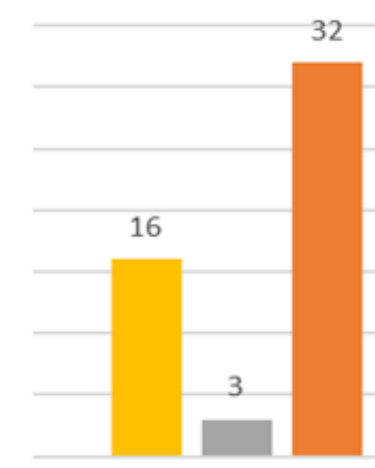

بائه هلمت

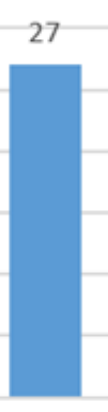

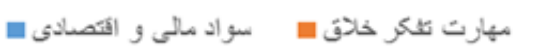

28

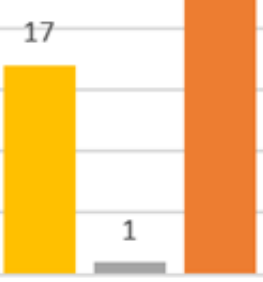

باياٍ هنتم

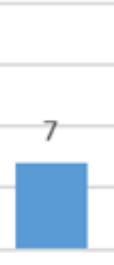

بحث و نتيجه كيرى بهمنظور وارسى الكوى مفهومى مؤلفههاى راهنمايى شغلى و كار آفرينى تلفيق شده در محتواى كتب درسى دوره متوسطه اول، مضامين مورد تأييد

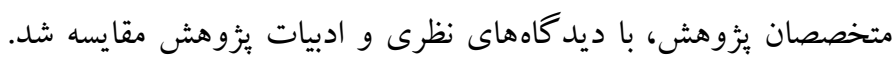
همجنين ميزان توجه به مضامين، كدها و مضامين مغفول و روند مضامين 
مورد در بايه نهم مشاهده شد و در يايه هفتم مغفول مانده است. بهعلاوه همه مراحل و كامهاى تصميم گيرى در قالب فعاليتى كه خود دانش آموز

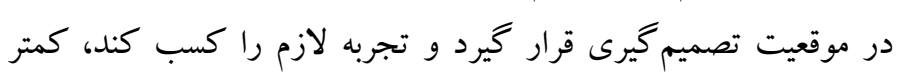
مشاهده شد. همجينين فعاليتها و تمرين هاس مرتبط با انتخاب و تصميم

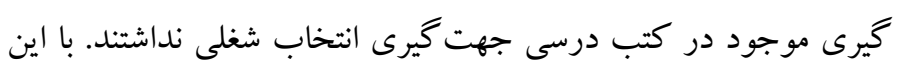

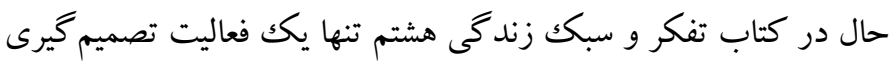

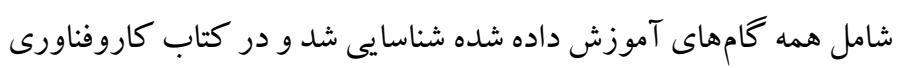

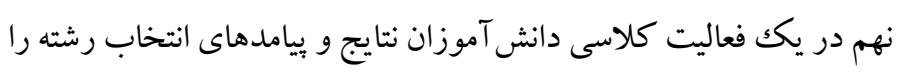
بررسى مى كنند. مغفول ماندن آموزش و تجربه يادگيرى مهارت انتخاب و تصميم گيرى

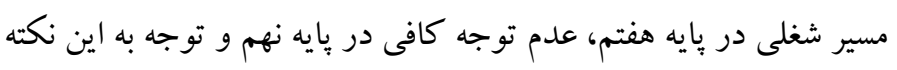

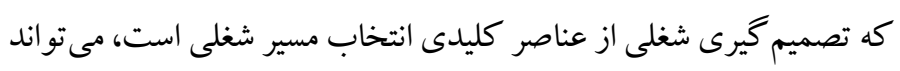

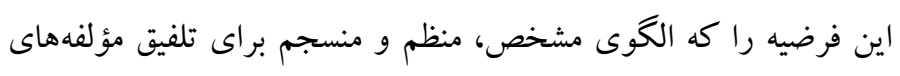

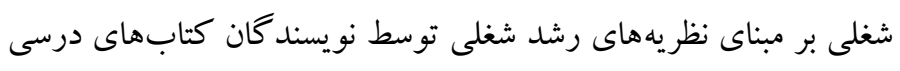

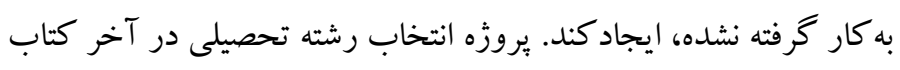

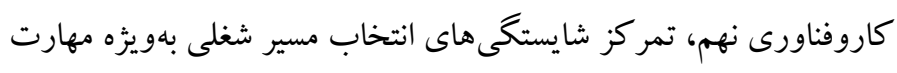

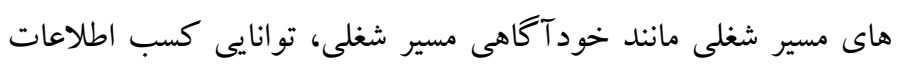

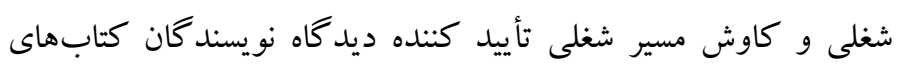
درسى بر آنى بودن انتخاب شغلى است.

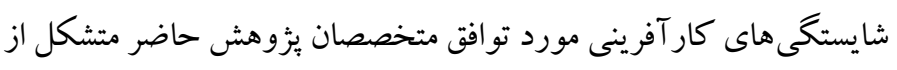

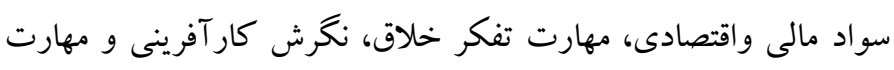
شناسايى و ارزيابى (و عمل به) فرصت با جداول طبقهبندى شده لاكئوس

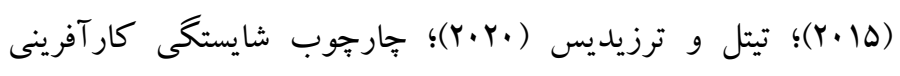

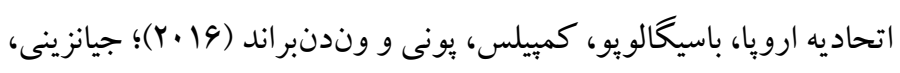

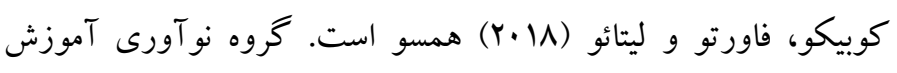
كار آفرينى ارويا (Y) (Y) معتقدند آموزش كار آفرينى در متوسطه اول، تمر كز بر توسعه مهارت هاى اساسى مانند: توسعه مفهوم، حل مسئله، تصميم

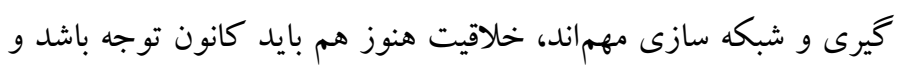
دانش آموز بايد فنون مختلفى را براى ايدهيردازى و استفاده كنند راهحل

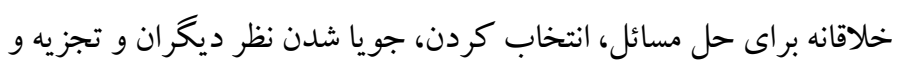
تحليل خطرات (ريسك) براى آموزش در اين سن مهم است، كه باديد كاه
مؤلفه هاى راهنمايى شغلى و كار آفرينى مستخرج از كتابهاى دوره اول متوسطه، جداكانه مورد تحليل و تبيين قرار كرفت.

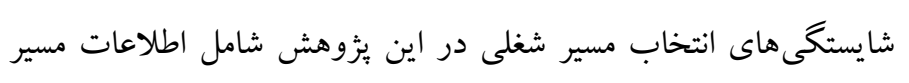

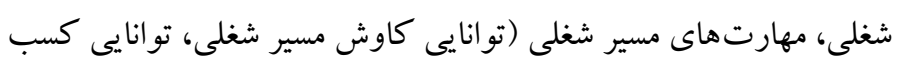

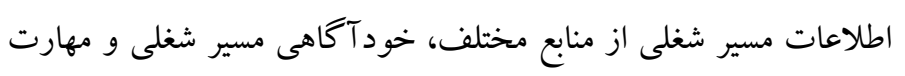

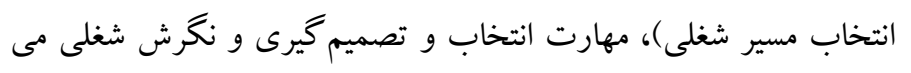
شوند. اطلاعات مسير شغلى بهعنوان بعد دانش بهترتيب در بايههاى هفتم تا نهم

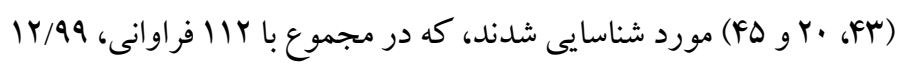
درصد از كل مضامين فرعى (بيشترين فراوانى در كل مضامين) به اين

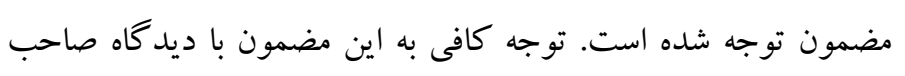
نظر ان و نظريه يردازان شغلى همسو ست. توجه اندكك به توانايى كسب اطلاعات مسير شغلى، خود آكاهى و كاوش مسير شغلى در محتو اى كتب بايه هفتم تا نهم، با مدل رشدى ايالت ميشيگان

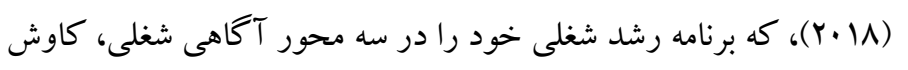

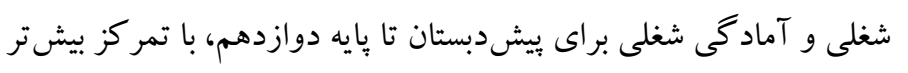

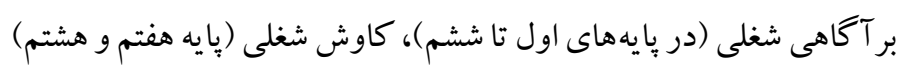
آمادكى شغلى'(نهم تا دوازدهم) سازمان داده، همجنين تأكيد نظام

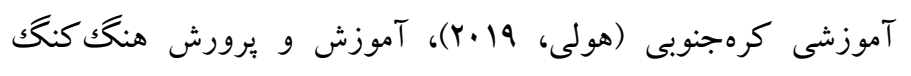

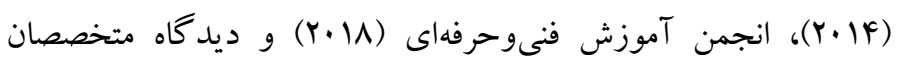

$$
\text { ئزوهش حاضر ناهمخوان است. }
$$

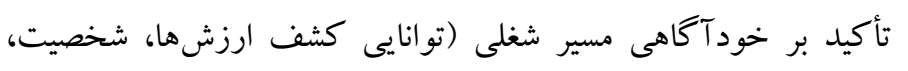

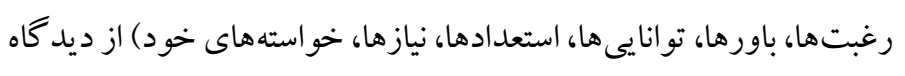
متخصصان بزوهش حاضر و اغلب نظريههاى انتخاب شغل نظير نظريههاى

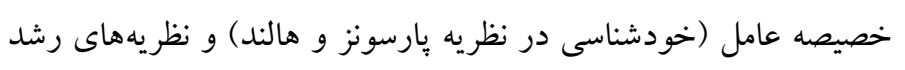

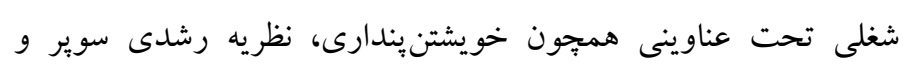

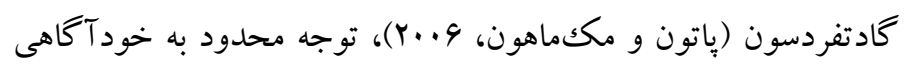
مسير شغلى در محتواى كتب درسى بايههاى هفتم و هشتم با ديدكاه متخصصان بزوهش حاضر و نظريههاى شغلى ناهمخوان است.

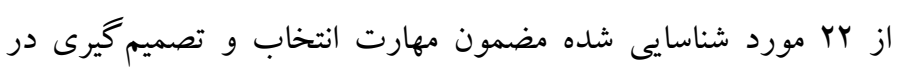

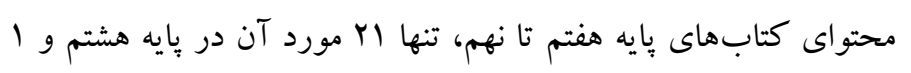

1. Career Preparation 
ديدن و كشف فرصتها (با بررسى و نياز سنجى در محيط مدرسه و جامعه

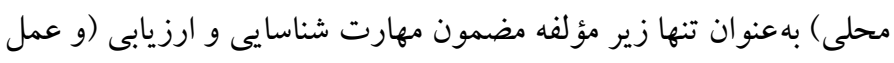

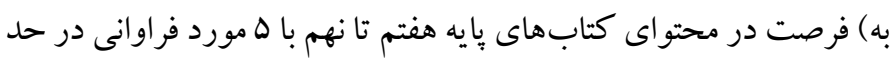
هايين تر از انتظار توجه شده است.

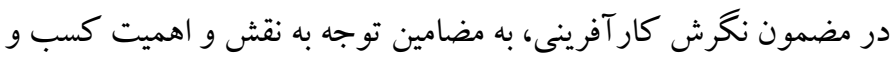

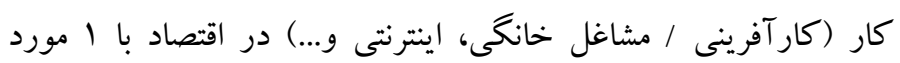

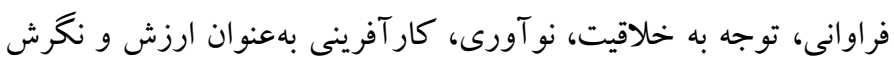

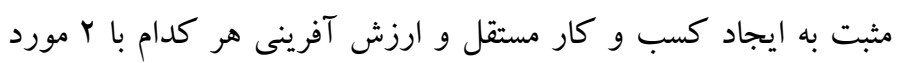

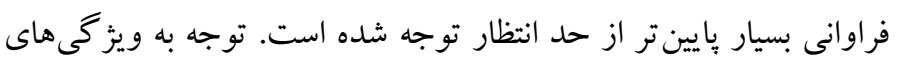
فردى كار آفرين موفق با لا مورد فراوانى در حد انتظار توجه شده است. از 19 مضمون بايه تأييد شده توسط متخصصان، دو مضمون بِ بايه مهارت

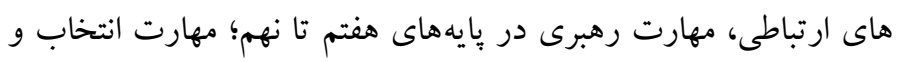

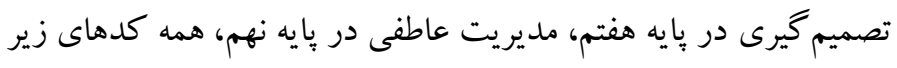

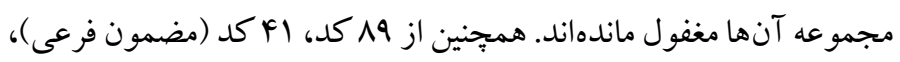

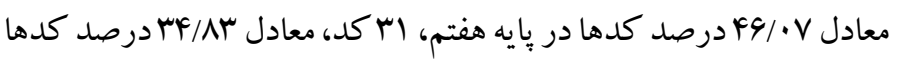

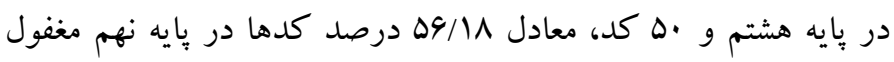
ماندهاند. در مجموع نتايج تبيين الخو نشان داد با توجه به مغفول ماندن درصد قابل توجهى از مضامين ضرورى در محتواى كتب درسى، روند تلفيق مهارت

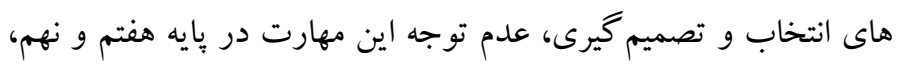
توجه اندك به مهارتهاى انتخاب مسير شغلى در بايه هفتم و هشتم، توجه

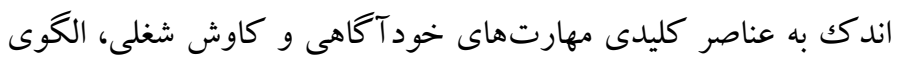

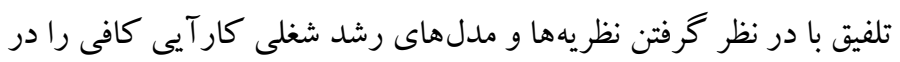

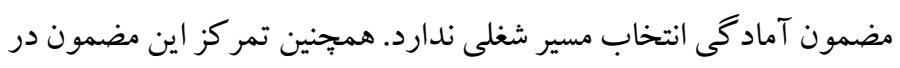

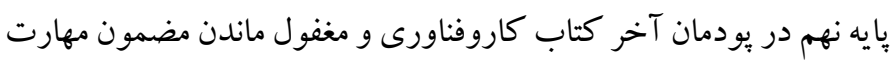
انتخاب و تصميم گيرى در يايه هفتم حاكى از غلبه ديد كاه آنى بر ديد كاه تكاملى انتخاب شغل در محتواى كتب درسى است. توجه اندك به به مضمون شناسايى و ارزيابى فرصت، سير نزولى ديخر مضامين شايستخى هاى

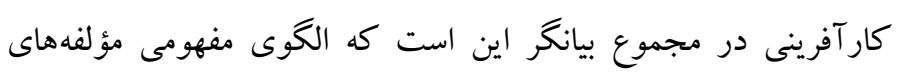

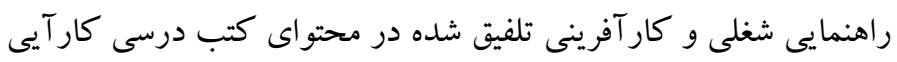

$$
\text { لازم را در آمادگى مسير شغلى دانش آموزان ندارد. }
$$

متخصصان يثزوهش حاضر در همه موارد جز تو انيى شبكهازى و تجزيه و تحليل ريسك همسوست. يافتهاى يُزوهش حاضر نشان مىدهد به مضامين مرتبط با شايستخى

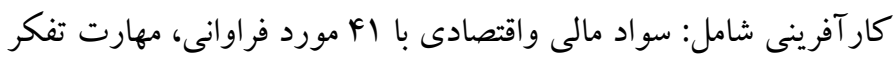

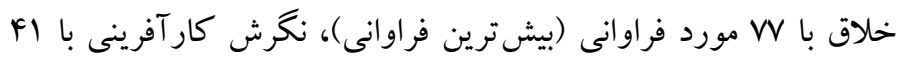

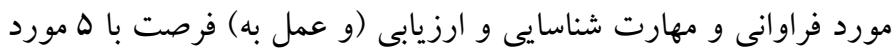

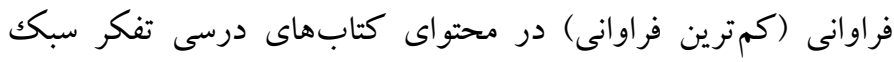

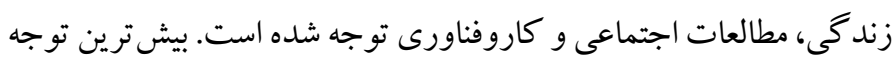

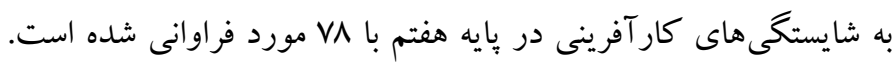
فراوانى مضمون سازماندهنده شايستخى كار آفرينى در بايه نهم با سام مورد

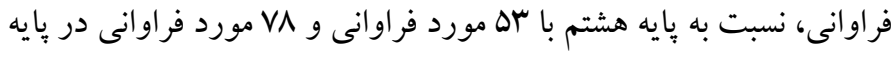

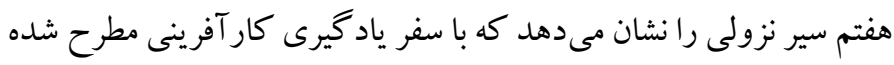

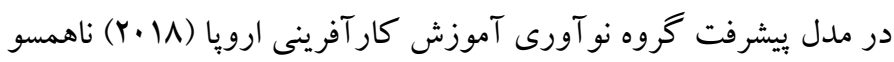
از ץ زيرمؤلفه مضمون سواد مالى و اقتصادى، به آشنايى با شيوههاى تامين

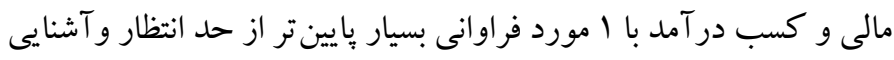

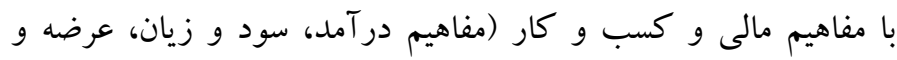

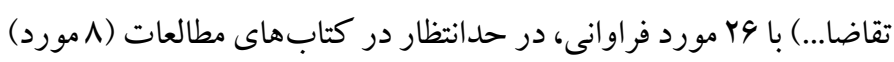

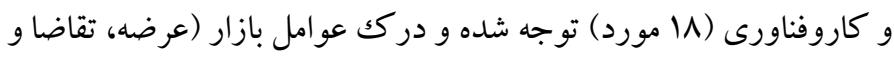

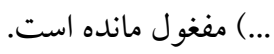
از 1 زيرمؤلفه مضمون مهارت تفكر خلاق، مضامين آشنايى و معرفى

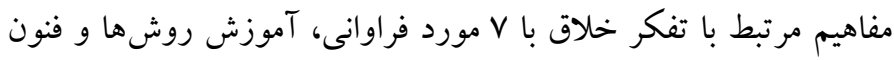

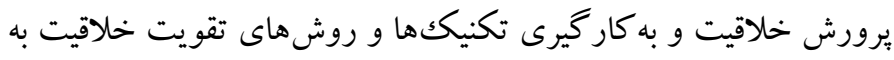

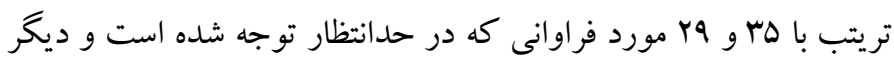
مضامين شامل: توانايى خلق ايده جديد، توانايى خلق راهحلها و اهداف

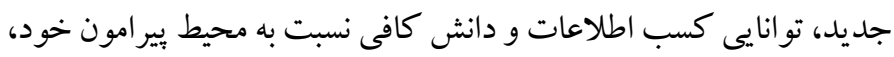
توانيى تفكر فراتر از جارجوب هاى موجود، شناسايى و برداشتن موانع

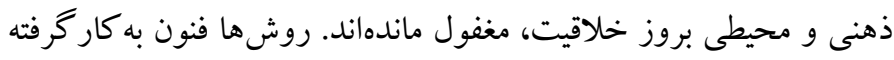

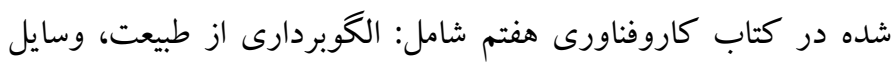
بيرامون، مخترعان و نو آوران براى براى خلق ايده، خلاقيت و نو آورىى،

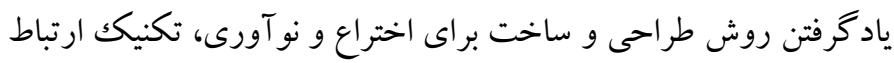
اجبارى و بارش فكرى مى شوند. 
نظريه هاى رشد شغلى است. همجِنين مضامين ضرورى مغفول مهارتهاى

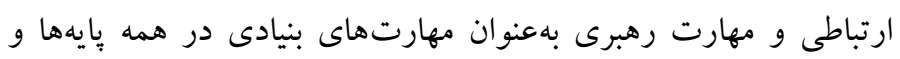

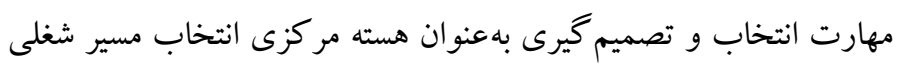

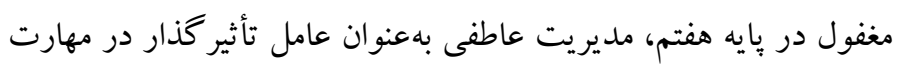

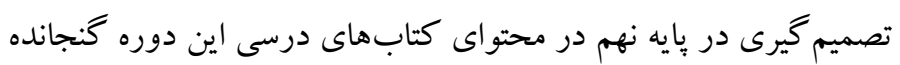
و به ديخر مضامينى كه كمتر توجه شده، توجه كافى شود.

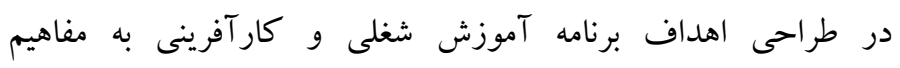
خود كارآمدى كار آفرينى و خود كار آمدى تصميم گيرى مسير شغلى به به آنه عنوان دو عنصر كليدى و بيشبينى كننده قصدكار آفرينانه و آماد

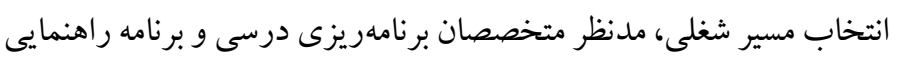
شغلى مدارس متوسطه اول قرار گيرد.

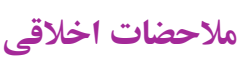
بيروى از اصول اخلاق ثئوهش: اين مقاله بركرفته از رساله دكترى نويسنده نخست

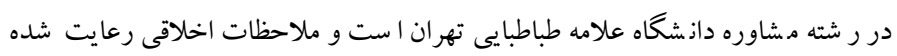

حامى مالى: اين مطالعه بدون حامى مالى و در قالب رساله دكترى انجام شده است.

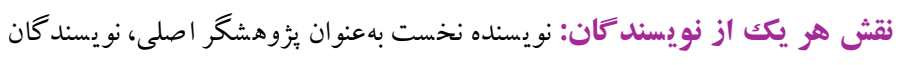

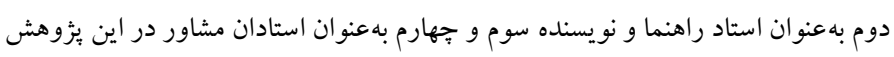
نقش داشتند.

تضاد منافع: اين يزوهش براى نويسند كان هيج گونه تضاد منافعى نداشته است.

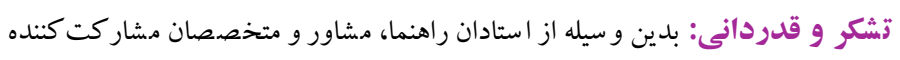
در اين يزوهش صميمانه تشكر و قدردانى مىشود.
يززوهش حاضر علاوه بر محدوديتهاى رايج يزوهش هاى كيفى و دامهاى

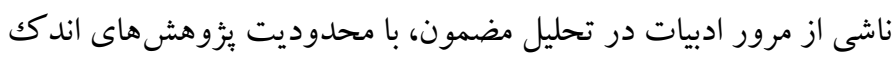

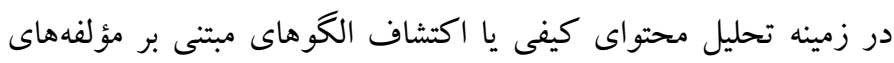

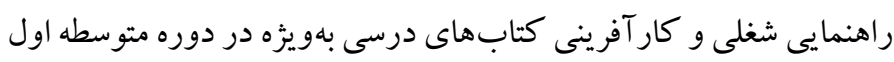

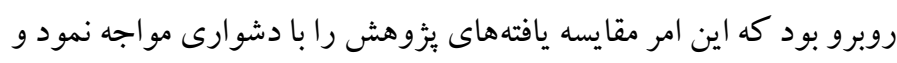

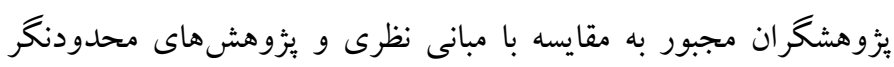

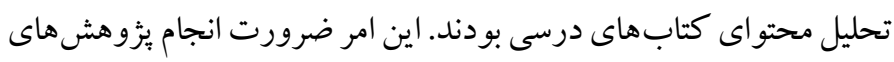

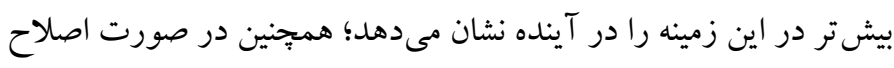

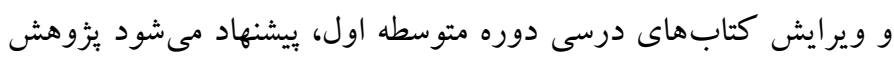

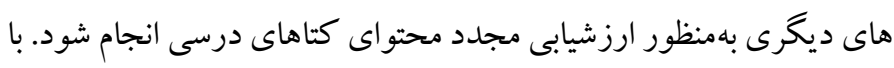

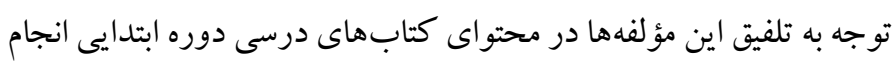
يثزوهش مشابه در دوره ابتدايى ضرورى بهنظر مئ مورسد.

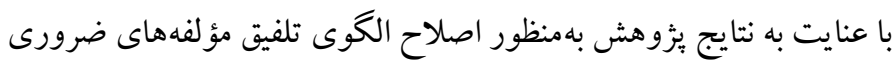
راهنمايى و كار آفرينى در كتابهاى درسى دوره متوسطه اول، در راستاى بناي تو انمندسازى آماد گى هاى انتخاب مسير شغلى و شايستخى هاى كار كار آفرينانه بيشنهادهاى زير نيز ارائه مىشود:

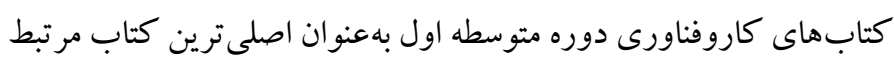

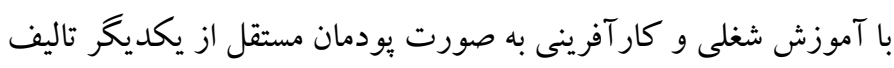

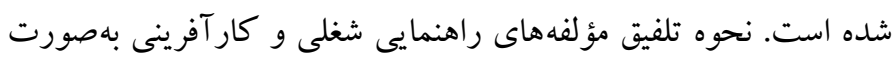
كسسته، نشاندهنده همخوانى سبك تأليف و تلفيق است. با اين حال بال

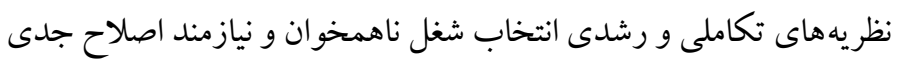

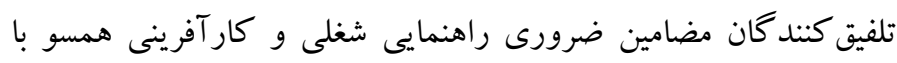




\section{References}

Abedi Ja'fari, H., Taslimi, M., Faghihi, A., Sheikhzade, M. (2011). Thematic Analysis and Thematic Networks: A Simple and Efficient Method for Exploring Patterns Embedded in Qualitative Data Municipalities). Strategic Management Thought, 5(2), 151-198. [Link]

Asgharnejād, K., Ranjdoust, S., Azimi, M. (2020). Explaining the components of the competencybased vocational training and analyzing its position in the non-technical competency textbooks of the second cycle high school technical and vocational and work and knowledge fields of education. Educational Innovations, 19(1), 31-46. [Link]

Association for Career and Technical Education. (2018). career exploration in middle school. Setting Students on the Path to Success. (ACTE) [Link]

Australian Blueprint For Career Development (2008). [Link]

Azizi, M., Mokhtari, N. (2018). Entrepreneurship education for knowing, doing and being in primary school with integrated approach. Journal of Entrepreneurship Development, 10(4), 635-654. [Link]

Bacigalupo, M., Kampylis, P., Punie, Y., Van den Brande, G. (2016). EntreComp: The entrepreneurship competence framework. Publications Office of the European Union. [Link]

Bahmani, N., Arasti, Z., Hoseini, S. (2018). Entrepreneurship education in elementry schools in order to improve entrepreneurial attitude. Journal of Entrepreneurship Development, 10(4), 555-574. [Link]

Braun, V. \& Clarke, V. (2006). Using thematic analysis in psychology. Qualitative Research in Psychology, Vol. 3, No. 2, Pp. 77-101. [Link]

Bridgstock, R., Grant-Imaru, M., \& McAlpine, A. (2019). Integrating career development learning into the curriculum: Collaboration with the careers service for employability. Journal of Teaching and Learning for Graduate Employability. 10(1). 5672. [Link]

Collins, J. and Barnes, A. (2017). Careers in the Curriculum. What works? London: The Careers \& Enterprise Company. [Link]

Dourandish, A., Nāderi, E., Seifnarāghi, M. (2019). Designing a competency-based curriculum framework for the industrial mechanics' discipline at the second cycle secondary school level. Educational Innovations, 18(3), 7-38. [Link]
Education Bureau (2014). Guide on Life Planning Education and Career Guidance for Secondary Schools. 1st Edition. HongKong. [Link]

European Commission (2012) Entrepreneurship Education at School in Europe. National Strategies, Curricula and Learning Outcomes. Brussels: Education, Audiovisual and Culture Executive Agency. [Link]

Godbey, S., \& Gordon, H. R. (2019). Career Exploration at the Middle School Level: Barriers and Opportunities. Middle Grades Review, 5(2). [Link]

Gianesini, G., Cubico S., Favretto G., Leitão G. C. C. (2018). "Entrepreneurial competences: comparing and contrasting models and taxonomies" in Entrepreneurship and the industry life cycle. Vol. 6, eds. [Link]

Gysbers, N. C. (2008). Career guidance and counselling In primary and secondary Educational settings. In Athanasou, J.A. \& Van Esbroeck, R. (Eds.). International Handbook of Career Guidance (pp. 249-264).) [Link]

Gysbers, N. C. (2013). Career-Ready Students: A Goal of Comprehensive School Counseling Programs. National Career Development Association. [Link]

Gysbers, N. C., Stanley, J. B., Bunch, L. K., Magnuson, C. S., and Starr, M. F. (2011). Missouri comprehensive guidance and counseling program. Warrensburg, Missouri: A Manual for Program Development, Implementation, Evaluation and Enhancement. Copyright of Missouri Center for Career Education, University of Central Missouri. [Link]

Hedayati, A., Maleki, H., Sadeghi A. R., \& Saadipour E. (2016). Contemplation on Competency-based Curriculum in Medical Education. Iranian Journal of Medical Education. [Link]

Hiebert, B. (2010) Comprehensive Guidance and Counseling in the Schools: Career-life Planning For All. Learning Achievement and career Development. International Association for Educational and Vocational Guidance. [Link]

Holmgren, C., \& From, J. (2005). Taylorism of the mind: Entrepreneurship education from a perspective of educational research. European Educational Research Journal, 4(4), 382-390. [Link]

Hooley, T. (2019). International approaches to quality in career guidance. Oslo: Skills Norway. [Link]

Hooley, T., Watts, A. G., and D. Andrews D. (2015). Teachers and careers. The role of school teachers in delivering career and employability learning. 
International Centre for Guidance Studies, University of Derby, Derby. [Link]

ICEE PROGRESSION MODEL. (2018). From the Entrepreneurship Competence Framework (EntreComp) to Practice in Schools. JA Europ www.icee-eu.eu [Link]

ITHACA Group (2019). Future Ready: Research on incorporating career education in the Australian Curriculum. commissioned by the Australian Government Department of Education and Training. [Link]

Lackéus, M. (2015). Entrepreneurship in Education. What, Why, When, Who. Centre for Entrepreneurship, SMEs, Tourism and Local Development. [Link]

Maghamdoost, A., Hatami, J., talaee, E., Shams, G. (2019). Designing and Validating an Optimal Pattern for Vocational Curriculum with an Entrepreneurial Approach. Journal of Curriculum Studies, 14(54), 117-152. [Link]

Mariani, M., Berger, C., Koerner, K., \& Sandlin, C. (2016). Operation occupation: A college and career readiness intervention for elementary students. Professional School Counseling, 20(1), 65-76. [Link]

McCallum, E. (2019). Entrepreneurial learning in TVET. Bantani Education. Coordinated by Miki Nozawa, Nickola Browne and Wouter de Regt (UNESCOUNEVOC). [Link]

Michigan Department of Education. (2018). Michigan Career Development Model. Michigan Department of Education, Office of Career and Technical Education. [Link]

Modarresi Saryazdi, A., Naderi, E., Seif Naraghi, M., Ahghar', G. (2018). Presentation of a theoretical model of entrepreneurship-oriented curriculum for Farsi courses at elementary school. Journal of Teaching Persian to Speakers of Other Languages, 7(TOME 15), 53-76. [Link]

Mueller, D., and Gozali-Lee, E. (2013). College and career readiness: A review and analysis conducted for Generation. Saint Paul, MN: Wilder Research. [Link]

Omidi, J., Hashemi, S. A., Gholtash, A., \& Mashinchi, A. (2019). Designing a curriculum design for entrepreneurship education for junior high School Students. Journal of Theory \& Practice in Curriculum. 7 (14):5-34 [Link]

Patton, Wendy and McMahon, Mary (2006) The Systems Theory Framework Of Career Development And Counseling: Connecting Theory And Practice.
International Journal for the Advancement of Counselling. 28(2): 153-16 [Link]

Palmer, H., \& Johansson, M. (2018). Combining entrepreneurship and mathematics in primary school - what happens? Education Inquiy. Vol. 9, No. 4, 331-346 [Link]

Sinay, E., \& Graikinis, D. (2018). Global competencies in deeper learning environments enabled by pervasive digital technologies: Evolving framework for theoretical foundation and developmental evaluation. Toronto, Ontario, Canada: Toronto District School Board [Link]

Sobhaninejad, Mahdi, Moghadam, Mina. (1392). Explain the dimensions and components of a comprehensive entrepreneurial attitude and analyze it in the content of general and complete skill textbooks and of Secondary Vocational Education. Journal of Educational Leadership and Management, 7 (1), 55-79. [Link]

Sultana, R. G. (2018). A Handbook on Enhancing the quality of career guidance in secondary schools. University of Malta. [Link]

Super, D. E. (1980). A life-span, life space approach to career development. Journal of Vocational Behavior, 16, 282-298. [Link]

UNESCO. (2017). Textbooks for Sustainable Development: A Guide to Embedding. New Delhi. Corporate author: UNESCO; Mahatma Gandhi Institute of Education for Peace and Sustainable Development (MGIEP) [Link]

Tittel, A., Terzidis, O. (2020). Entrepreneurial competences revised: developing a consolidated and categorized list of entrepreneurial competences. Entrep.Educ., 3, 1-35. [Link]

Watts, A.G. (2001). Career Education for Young People: Rationale and Provision in the UK and Other European Countries. International Journal for Educational and Vocational Guidance, Vol.1, No.3, pp. 209-222. [Link]

Watts, A.G. (2009). The Relationship of Career Guidance to VET, OECD, Paris. [Link]

Watts, A.G. (2010). Career Guidance and Post-Secondary Vocational Education and Training. A paper prepared for the OECD Review of Post-Secondary Vocational Education and Training, Skills beyond School. Paris: OECD. [Link]

Wood, C., \& Kaszubowski, Y. (2008). The career development needs of rural elementary school students. The Elementary School Journal, 108(5), 431-444. [Link] 